\title{
PKK'da Kadın Teröristlerin Rolü ve Örgüt İçi Cinsel İstismar
}

\author{
The Role of Female Terrorists \\ and Sexual Abuse in the PKK
}

$\ddot{O} z$

Terör örgütleri mevcudiyetlerini devam ettirebilmek için sürekli yeni elemanlar devşirmeye muhtaçtırlar. 20. yüzyılda kadının toplumsal hayattaki ve iş hayatındaki rolünün artmasının da etkisiyle terör örgütleri kadınları örgüt içerisinde çeşitli rollerde kullanmıştır. Savaşmalarının yanı sıra çoğu zaman ikincil rollerde - kuryelik, aşçılık, temizlikçi vb. kullanılan kadınlar, intihar saldırılarını gerçekleştirmede çeşitli avantajlara sahip olmalarindan dolayı bu eylemlerde de siklikla tercih edilmektedir. Ayrıca bazı terör örgütlerinde kadınlar, cinsel kimlikleri ön plana çıkarllarak "yem" veya "cinsel köle" olarak da kullanılmaktadır. Çalışmada PKK'da kadın teröristlerin intihar saldırılarındaki kullanımı ve örgüt içerisinde maruz kaldıkları cinsel istismar ele alınmaktadır. Çalışmanın ana argümanı örgüt lideri Abdullah Öcalan tarafindan yapılan kadın tanımlamasının gerçeği yansıtmadığı, PKK'da kadın-erkek eşitliğinin bulunmadiğı ve kadınların sıklıkla cinsel istismara maruz kaldiğı yönündedir. Terör çalışmaları ve kadın konusunda literatürde PKK üzerine sinırl sayıda çalışma olması ve çoğunlukla örgütün cinsel

\footnotetext{
* Doç. Dr., Türk - Alman Üniversitesi Siyaset Bilimi ve Uluslararası İlişkiler Bölümü, ORCID: 0000-0002-5039-3493, e-posta: bayrakli@ tau.edu.tr.

** Doktora Öğrencisi, İstanbul Medeniyet Üniversitesi Uluslararası İlişkiler Bölümü, ORCID: 0000-0002-8682-5569, e-posta: aslihanalkanat@ gmail.com.
}

Geliş Tarihi / Submitted: 05.01.2021

Kabul Tarihi / Accepted: 02.03.2021 
120

Güvenlik Stratejileri

Cilt: 17

Sayı: 37

istismar suçlarının göz ardı edilmesi nedeniyle bu çalışmanın literatürde önemli bir boşluğu dolduracă̆ düşünülmektedir.

Anahtar Kelimeler: Terör Örgütleri, Kadın Teröristler, PKK, Cinsel Istismar, Intihar Saldırlart.

\section{Abstract}

Terrorist organizations need to recruit new militants in order to maintain their existence. In the 20th century, the role and visibility of women in social and business life has increased, which also led to an increasing recruitment of female terrorists for various roles and purposes. Besides engaging in terrorism activities female terrorists are also used in secondary roles such as courier, cooker, cleaner, etc. They are also frequently preferred in suicide attacks as they have various advantages over male terrorists in carrying out these attacks. Furthermore, some terrorist organizations also use female terrorists as a "bait" or "sexual slaves" by putting their sexual identities in the foreground. This paper analyses the role of female terrorists in the suicide attacks carried out by $P K K$ and the sexual abuse experienced by female terrorists. The main argument of the study is that Abdullah Öcalan's claims about women emancipation in the PKK do not reflect the reality. On the contrary women are not equal to men in the PKK and they are often exposed to sexual abuse. This study aims to fill an important gap in the literature, since there are a limited number of studies about the role of female terrorists and sexual abuse against them in the PKK.

Keywords: Terrorist Organizations, Female Terrorists, PKK, Sexual Abuse, Suicide Attacks.

\section{Giriş}

Terör örgütlerinin evirilmesi ve yapısında yaşanan değişimler ile özellikle örgütlerin kadın algısında önemli değişimler gerçekleşmiştir. Başlangıçta terör örgütlerinde kadınların örgüt içerisindeki işlevlerinin kısıtlı olduğuna yönelik bir algı mevcutken bu algı değişime uğramış, kadınlar terör örgütleri tarafından çeşitli rollerde kullanılmak üzere daha çok tercih edilmeye başlanmış ve kadın teröristlerin sayısı zamanla artış göstermiştir. Çalışmanın ilerleyen kısımlarında ele alınacă̆ 1 gibi, 
özellikle örgütlerin intihar saldırılarında sıklıkla tercih ettiği kadın teröristler, örgüt içerisinde çatışmalara katılmanın yanı sıra ikincil rollerde de kullanılmış ve çoğunlukla örgütün iç dinamiklerini dengeleme amacıyla terör örgütleri tarafından tercih edilmiştir. Dünyada birçok terör örgütü tarafından kullanılan kadın teröristler, PKK içerisinde de çeşitli rollerde kullanılmaktadır. Özellikle 1990'lardan itibaren kadın teröristlerin sayısı örgüt içerisinde artış göstermiş ve kadınlar intihar saldırıları, aşçılık, bilgi taşıyıcılı̆̆ı gibi rollerde aktif yer almıştır. Ancak dünya üzerindeki terör örgütlerinde kadınların yaşadığı en büyük problemlerden birinin; cinsel istismara uğramak ve cinsel köle olarak kullanılmak olduğu söylenebilir. $\mathrm{Bu}$ problemler terör örgütlerinin çoğunda mevcut olmakla birlikte PKK içerisinde de gerek güvenlik güçlerinin raporlarında gerekse teslim olan/yakalanan teröristlerle yapılan mülakatlarda ortaya çıkmaktadır.

Çalışmada öncelikle kadınların terör örgütlerindeki rolü açıklanarak, örgütlerin neden kadınlara ihtiyaç duyduğu anlatılacaktır. Daha sonra terör örgütlerinde ihtiyaç duyulan kadınların, örgütler için hem maliyet açısından ucuz hem de görece daha etkili olan intihar saldırılarındaki rolü ele alınacaktır. Çalışmanın ikinci bölümünde PKK'daki kadın teröristlerin konumu incelenecektir. Bu bölümde PKK'nın ve terörist başı Abdullah Öcalan'ın tarihsel süreç içerisinde kadına bakış açısında yaşanan değişimin üzerinde durulacak ve daha sonra PKK tarafindan kadın teröristlerin neden tercih edildiğine ve örgütün ideolojik olarak kadın ve aile konusundaki yaklaşımına değinilecektir. İkinci bölümün alt başl1klarından biri olan ve PKK'nın sıkça kullandığı bir yöntem olan intihar saldırılarında PKK'lı kadın teröristlerin rolü anlatılacaktır. Çalışmanın ikinci bölümünün ikinci alt başlığında ise $\mathrm{PKK}^{\prime}{ }^{1}$ kadın teröristlere yönelik örgüt içerisinde gerçekleşen cinsel istismarlara değinilecektir. Bu bölüm aynı zamanda çalışmanın temel konusunu oluşturmaktadır.

Çalışma, PKK içerisinde yer alan kadın teröristlerin rolünü açıklaması açısından önem arz etmektedir. Çalışmanın ana argümanı ise Abdullah Öcalan tarafindan dile getirilen "özgürleştirilen kadınlar" söyleminin gerçeği yansıtmadığı ve kadın teröristlerin örgüt içerisinde kadın-erkek eşitliğine dayalı bir yapıdan ziyade kadınların cinsel

\section{1}

Güvenlik Stratejileri

Cilt: 17

Say1: 37 
122

Güvenlik Stratejileri

Cilt: 17

Sayı: 37

sömürüyle karşı karşıya kaldığı bir yapıyla muhatap oldukları yönündedir. Çalışmada söz konusu cinsel sömürü teslim olan terörist itiraflarına, kadın teröristlerle yapılmış ve yayınlanmış röportajlardan elde edilen bilgilere dayanmaktadır. Aynı zamanda Öcalan'ın kadın ve aile gibi konulardaki söylemlerine yer verilerek yapılan röportajlar kapsamında kadınların örgüt içerisindeki rolü analiz edilmektedir. Karma bir metodolojik yöntem izlenilen çalışmada, hem Öcalan ve teslim olan teröristlerin yayınlanmış röportajları hem de haberler ve raporlar gibi ikincil kaynaklar kullanılarak bir analiz gerçekleştirilmektedir. Ayrıca çalışmada terörizm çalışmaları kapsamında "seküler ve dini eğilimli terör örgütleri" ş̧eklinde yapılan sınıflandırma tercih edilerek PKK, ideolojisi ve eylemleri çerçevesinde seküler terör örgütleri içerisinde değerlendirilmektedir.

\section{Kadınların Terör Örgütlerindeki Rolü}

Birçok terör örgütü tarafindan tercih edilen kadın teröristlerin terör örgütlerindeki rolü üzerine yapılan akademik çalışmalar içerisinde IRA (Irish Republican Army), ETA (Euskadi Ta Askatasuna), Tamil Kaplanları, Boko Haram ve DEAŞ (Devlet'ül Irak ve'ş Şam) gibi örgütlerde kadınların rolüne dayalı çalışmalar bulunmaktadır. Örneğin; ETA'da örgüt içerisinde aile bağları, kadın-erkek ilişkileri tamamen ikinci plana atılmış ve kadın-erkek arasında cinsel ilişki de yasaklanmıştır. “Erkek kardeşlik" miti bulunan örgüte 1960'lı yıllarda kadınların katılımı oldukça az olmasına rağmen kadın teröristlerin örgüte katılımı 1970'lerden itibaren artış göstermiştir. ${ }^{1}$ IRA'daki kadın teröristler ise örgütün kuruluşundan beri örgüt içerisinde aktif bir rol almıştır. Kadınlar, hapishanelerdeki erkeklere yardım sağlamada, aşçılık ve maddi destek gibi konularda destekte bulunmuştur. ${ }^{2}$ IRA'nın yapısına bakıldığında, kadın-erkek ilişkileri örgüt içerisinde sınırlandırılarak özellikle kadınların

1 Carrie Hamilton, Women and ETA: The Gender Politics of Radical Basque Nationalism, Manchester University Press, Manchester, 2007, s. 88-89.

2 Ann Mathews, Renegades: Irish Republican Women: 1900-1922, Mercier Press, 2010, s. 15. 
PKK’da Kadın Teröristlerin Rolü ve Örgüt İçi Cinsel İstismar

cinsel ilişki yaşaması yasaklanmış ve bekâr kadın teröristlerden örgüt içerisinde hamile kalan olması durumunda örgütten atılmıştır. ${ }^{3}$

Son dönemde akademik çalışmalarda oldukça yaygın bir şekilde yer alan DEAŞ'ta ise kadınların örgüt tarafından "cezalandırma" stratejisi kapsamında cinsel istismara maruz bırakılarak cinsel köle olarak kullanılmasından söz edilmektedir. ${ }^{4}$ Terörizm, kadın ve cinsel istismar konusunda sıklıkla çalışmalar yapılan bir başka terör örgütü de Nijerya'da bulunan Boko Haram'dır. Boko Haram'ın okullardan kiz çocuklarını kaçırıp tecavüz, cinsel istismar ve zoraki evlilik gibi eylemlerde bulunduğundan söz edilmektedir. Örneğin; Nisan 2014'te Boko Haram 276 kız çocuğunun da içerisinde bulunduğu binlerce kadını kaçırarak örgütteki erkek teröristlerle zorla evlendirmiş ve kadınları cinsel köle olarak kullanmıştır. ${ }^{5}$ Son dönemde terör örgütleri içerisinde kadınların oranının artması sebebiyle birçok örgütte kadınerkek ilişkilerine dair benzer sınırlandırmalar getirildiği ve kadınların cinsel istismar gibi benzer problemler yaşadıkları görülmektedir. Çalışmanın konusunu oluşturan PKK'nın örgüt ideolojisi kapsamında kadın-erkek ilişkilerini ele alan akademik çalışmalar incelendiğinde ise çalışmaların oldukça sınırlı olduğu görülmektedir. ${ }^{6}$ Örgüt içerisinde kadınlara yönelik cinsel istismarın ele alındığı çalışmalar da genellikle teslim olan teröristlerle yapılan röportajlarla sınırlı kalmakta ve bu konuda literatürde boşluk olduğu görülmektedir.

Günümüzde kadınlar, terör örgütleri içerisinde aktif bir şekilde

\footnotetext{
${ }^{3}$ Age, s. 251.

${ }^{4}$ May-Rukh Ali, "ISIS and Propaganda: How ISIS Exploits Women", University of Oxford Reuters Institute for the Study of Journalism, 2015, 1-25, https://reutersinstitute. politics.ox.ac.uk/sites/default/files/research/files/Isis\%2520and\%2520Propaganda-\%2520 How\%2520Isis\%2520Exploits\%2520Women.pdf, (Erişim Tarihi: 28.10.2020).

5 5th Gobal Report: Sexual Exploitation New Challenges, New Answers, Fondation Scelles, 2019, s. 366, http://fondationscelles.org/pdf/RM5/5th_Global_Report_Fondation_ SCELLES_2019_download.pdf, (Erişim Tarihi: 28 Ekim 2020).

${ }^{6} \mathrm{Bu}$ çalışmalara örnek olarak bkz; H. Bahadır Türk, "Hegemonic Masculinity and Terrorism: The Case of The PKK and Abdullah Öcalan", Critical Studies on Terrorism, 2020, Cilt 13, Say1 2, 258-279.
}

\section{3}

Güvenlik Stratejileri

Cilt: 17

Say1: 37 
124

Güvenlik Stratejileri

Cilt: 17

Sayı: 37

azımsanamayacak oranda yer almaktadır. Özellikle küreselleşmenin de etkisiyle toplumda kadının konumu ve rolünde değişim meydana gelmiş ve bu değişimin yaşandığ bir başka alan da terör örgütleri olmuştur. 1965'li yıllardan itibaren kadınlar, özellikle radikal sol terör örgütlerine katılmaya başlamış olsa da kadınların terör örgütlerine yoğun bir şekilde katılımı 1980'li y1llardan itibaren dini eğilimli terör örgütlerinin de kadın teröristlere örgüt içerisinde yer vermesiyle gerçekleșmiștir. ${ }^{7}$ Çeşitli nedenlerden terör örgütlerine katılan kadınların hem seküler hem de dini eğilimli terör örgütleri içerisinde son y1llarda daha aktif bir şekilde yer aldığ 1 görülmektedir. Başlangıçta dini terör örgütleri kadınların örgütlere katılımı konusuna daha mesafeli yaklaşırken; seküler terör örgütleri ise kadınların örgüt içerisinde yer almasına daha çabuk uyum sağlamıştır. Yapılan ampirik çalışmalarda da kadınların gerçekleştirmiş olduğu saldırıların yüzde 85 'i, kadın-erkek eşitliğini ön plana çıkaran söylemleri bulunan seküler terör örgütlerindeki kadın teröristler tarafindan gerçekleştirilmiştir. ${ }^{8}$ Söz konusu eşitlikçi söylemlerden etkilenerek terör örgütlerine katılan kadınların ise ideallerinin aksine daha farklı görevlerde kullanıldığı görülmektedir. Terör örgütlerinde aktif bir şekilde rol alan kadınlara hem dini hem de seküler terör örgütlerinde genellikle "ikincil terörist" sinıflandırması yapılmakta ve kadınlar örgütlerde çoğunlukla temizlik, kurye, bekçi, gibi işlerde kullanılmaktadır. Bunların yanı sıra kadın teröristler; eğitmen, bomba yapımcıs1, intihar eylemcisi, hava korsan1, güvenlik elemanı, bal tuzağı,${ }^{9}$ sabotajcı, eş, silah ve mühimmat taşıyıcısı, ${ }^{10}$ mayın temizleyicisi,

7 Şükrü Okyar Çebi, "Terörizm Olgusu İçerisinde Kadın Militanların Analizi”, Yayınlanmamış Yüksek Lisans Tezi, 2010, s. 1-2.

${ }^{8}$ Lindsey A. O'rourke, "What's Special about Female Suicide Terrorism?", Security Studies, 2009, Cilt 18, Say1 4, 681-718, s. 693-696.

${ }^{9}$ Bal Tuzağı (Honey Trap): Kadınların cinselliklerinin kullanılarak erkeklerden bilgi alması veya örgüt içerisinde erkek elemanları devşirmek amacıyla kullanılması. Bal tuzağı yöntemlerine birçok terör örgütü başvurmaktadır. Örneğin; Pakistan'da terörist gruplar bu yöntemi kullanarak örgüte erkek teröristleri devşirmektedir. ("Pakistan Terror Groups Use Women to 'Honey Trap' Youths: Officials", Economic Times, 3 Aralık 2018, https://economictimes.indiatimes.com/news/defence/pakistan-terror-groups-use-women-to- 
PKK’da Kadın Teröristlerin Rolü ve Örgüt İçi Cinsel İstismar

hasta bakıc1, istihbarat toplayıc1 ${ }^{11}$ gibi birçok farklı konumda kullanılmaktadir.

Bunların yanı sıra genellikle örgütlerin yönetim kadrolarında erkeklerin bulunması dolayısıyla da örgüte katılan kadınların yalnızca bahsi geçen görevlerde kullanılmadığı, aynı zamanda cinsel anlamda da sömürüldüğü bilinmektedir. ${ }^{12}$ Öncelikle kadınların cinsel kimliği, teröre eğilimli erkekleri terör örgütü içerisine çekme konusunda bir "yem" olarak kullanılmaktadır. Benzer şekilde erkek teröristlerin örgütteki devamlılıklarının sağlanması amacıyla da kadınların cinsel olarak sömürüldüğü bilinmektedir. Hatta terör örgütleri tarafından örgüte kadınların katılımı söz konusu hedefler doğrultusunda da desteklenmektedir. Özellikle Marksist ideolojinin benimsendiği terör örgütlerinde tek eşliliğe yönelik eleştiriler kapsamında örgüt içerisindeki kadın-erkek ilişkileri şekillendirilmektedir. Örneğin; 1973-1975 yılları arasında ABD'de aktif olarak faaliyet gösteren radikal sol terör örgütü SLA (Symbionese Liberation Army) içerisinde kadınların erkeklerle cinsel birlikteliğe zorlanmamasına rağmen söz konusu birlikteliğin kabulünün "yoldaşça" görülmesi dolayısıyla kadınların cinsel sömürüye r1za gösterdiği bilinmektedir. ${ }^{13}$

Kadınların cinsel kimliği dolayısıyla tercih edilmesinin yanı sıra intihar saldırılarında da sıklıkla kullanıldığı bilinmektedir. İntihar bombacılı̆̆ı, taktiksel açıdan basit ve maliyetinin az olması, intihar

honey-trap-youths-officials/articleshow/66906490.cms?utm_source=contentofinterest\&utm _medium=text\&utm_campaign=cppst, (Erişim Tarihi: 30.10 .2020$)$.

${ }^{10}$ Anne Speckhard, "Female Terrorists in ISIS, al Qaeda and 21rst Century Terrorism", Trends Research, May1s 2015, 1-9, s. 6, https://www.researchgate.net/profile/Anne_ Speckhard/publication/277204743_Female_Terrorists_in_ISIS_al_Qaeda_and_21rst_Centu ry_Terrorism/links/556472a908ae86c06b6a76c5/Female-Terrorists-in-ISIS-al-Qaeda-and21rst-Century-Terrorism.pdf, (Erişim Tarihi: 11.09.2020).

${ }^{11}$ Necati Alkan, PKK'da Semboller, Aktörler, Kadınlar, Karınca Yayınları, Ankara, 2017, s. 67.

${ }^{12}$ Deborah M. Galvin, "The Female Terrorists: A Socio -Psychological Perspective", Behavioral Sciences \& The Law, 1983, Cilt 1, Say1 2, 19-32, s. 23-25.

${ }^{13}$ A.g.e, s. 25-26.

\section{5}

Güvenlik Stratejileri

Cilt: 17

Say1: 37 
126

Güvenlik Stratejileri

Cilt: 17

Sayı: 37

bombacısının zaman ve mekânı seçebilmesi nedeniyle zayiatın yüksek olması, teröristlerin kolluk kuvvetleri tarafından yakalanıp sorgulanma gibi bir ihtimalinin bulunmaması ya da çok az olması ve hem halk üzerinde hem de medyada büyük bir psikolojik etkiye sahip olması açısından terör örgütleri tarafından kullanılmaktadır. ${ }^{14}$ Terör örgütleri, intihar bombacılarının seçiminde yaş veya cinsiyet ayrımı yapmamakla birlikte, genellikle kadınları tercih etmektedir.

Kadınların intihar saldırılarında terör örgütleri tarafından tercih edilmesinin birçok sebebi bulunmaktadır. Bunlar arasında; öncelikle yapılan araştırmalarda kadınların gerçekleştirmiş olduğu intihar saldırılarının erkeklerin gerçekleştirdiklerine oranla daha fazla zarar verdiği ortaya çıkmıştır. Özellikle kadın teröristlerin bulundukları toplumda kadın-erkek eşitsizliği mevcutsa ve kadına atfedilen roller sınırlıysa, eşitsiz muameleye maruz kalan kadın teröristlerin gizlenme potansiyelini en üst düzeye çıkararak erkeklere göre daha ölümcül saldırılarda bulunduğu belirtilmektedir. ${ }^{15}$ Aynı zamanda cinsiyet farkı dolayısıyla kadınların kontrol noktalarından geçerken erkekler kadar detaylı bir aramaya maruz kalmaması, hamilelik süsü vererek kolaylıkla kontrol noktalarından geçebilmeleri, toplumda kadınların "şiddetten uzak kişiler" olduğuna yönelik algı, örgütlerin tanıtımının ve propagandasının yapılmasında kadınların daha etkili olması ve teröristler arasinda daha fazla psikolojik etkiye sebep olmas1 gibi nedenler sayılabilmektedir. ${ }^{16}$ Benzer şekilde intihar saldırılarını gerçekleştiren kadın teröristlerin hedef ülke içerisinde mağduriyet yaşadığı argümanıyla hem ulusal hem de uluslararası düzeyde medya aracılığıla etki oluşturduğu da gözlenmektedir. ${ }^{17}$ Aynı zamanda küreselleşmenin ve liberal düzenin de etkisiyle kadınların toplumsal rollerinde meydana

14 Ehud Sprinzak, "Rational Fanatics", Foreign Policy, 20 Kasım 2009, https://foreignpolicy.com/2009/11/20/rational-fanatics/, (Erişim Tarihi: 21.08.2020).

${ }^{15}$ O'rourke, a.g.e., s. 685.

${ }^{16}$ Debra D. Zedalis, "Female Suicide Bombers", The Strategic Studies Institute, June 2004, 1-18, s. 7.

${ }^{17}$ O'rourke, a.g.e. , s. 702. 
PKK'da Kadın Teröristlerin Rolü ve Örgüt İçi Cinsel İstismar

gelen değişim ile terör örgütleri sadece operasyonel kolaylıklar ve fırsatlar açısından değil, örgütün imajı ve kadının değişen rolüne de vurgu yaparak söz konusu kadın imajını bir propaganda aracı olarak kullanmak amaciyla da buna önem vermiştir. Tüm bu nedenlerden ötürü hem seküler hem de dini eğilimli terör örgütleri tarihsel süreç içerisinde kadınları örgüt içerisinde ve özellikle intihar eylemlerinde sıklıkla kullanmayı tercih etmiştir.

Aşağıdaki grafikte de 1985-2006 yılları arasında gerçekleşen intihar saldırılarında en çok kadın intihar bombacısının kullanıldığı ülkelere yer verilmiştir.

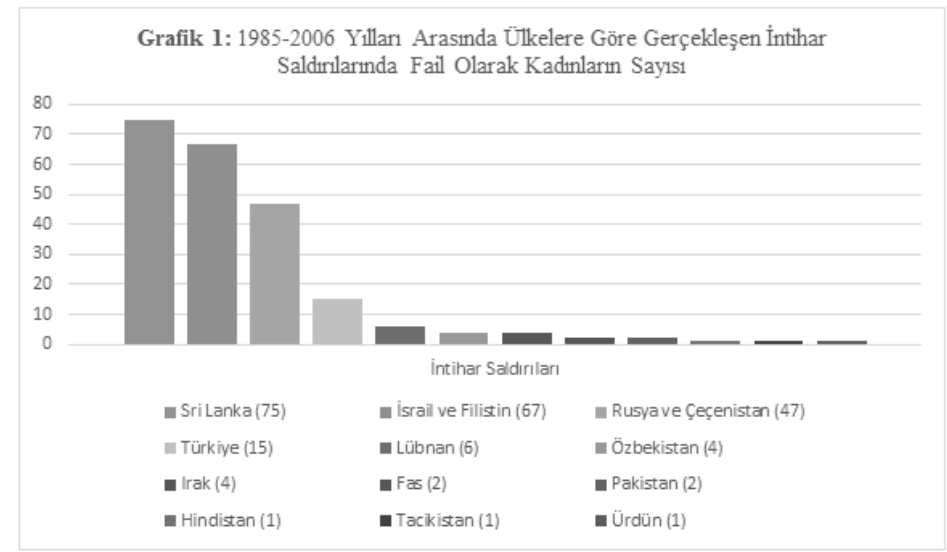

Kaynak: Yoram Schweitzer, Female Suicide Bombers: Dying for Equality?, Tel Aviv University, Jaffee Center for Strategic Studies, 2006, s. 8'den aktaran; Necati Alkan, PKK'da Semboller, Aktörler, Kadınlar, Karınca Yayınları, Ankara, 2017, s. 68.

Yukarıdaki grafikte 1985-2006 yılları arasında gerçekleşen intihar saldırılarında failin kadın teröristler olduğu eylemlerin sayısı ülke bazında incelenmiştir. Bu aralıkta intihar saldırılarında en fazla kadının kullanıldığı ülke Sri Lanka'dır. Türkiye ise PKK terör örgütünün intihar saldırılarında kadınları sıkça kullanması dolayısıyla dördüncü sırada yer almakta ve böylece PKK içerisinde de kadınların intihar saldırılarında aktif olarak yer aldığ 1 görülmektedir.

\section{7}

Güvenlik Stratejileri

Cilt: 17

Say1: 37 
128

Güvenlik Stratejileri

Cilt: 17

Sayı: 37

\section{PKK'nın Kadın Teröristleri}

Türkiye'de 1979 'da ilk terör eylemini gerçekleştiren PKK'ya 1990'lardan itibaren kadın teröristlerin katılımında artış yaşandığı bilinmektedir. PKK içerisindeki kadın teröristlerin oranı hakkında kesin bir bilgi bulunmamakla birlikte, TEPAV tarafindan 2001-2011 yılları arasında PKK'lı teröristler üzerine yapılan bir araştırmada; kadın teröristlerin PKK içerisindeki oranı yüzde 12 olarak belirtilmiştir. Azımsanamayacak bir oranı bulunan PKK' 1 kadın teröristlerin örgütte ölüm yaşının ise ortalama 26 olduğu tespit edilmiştir.18 Teröristlerin örgütte bulunma süreleri üzerine yapılan çalışmada ise şu şekilde bir sonuca ulaşı1mıştır:

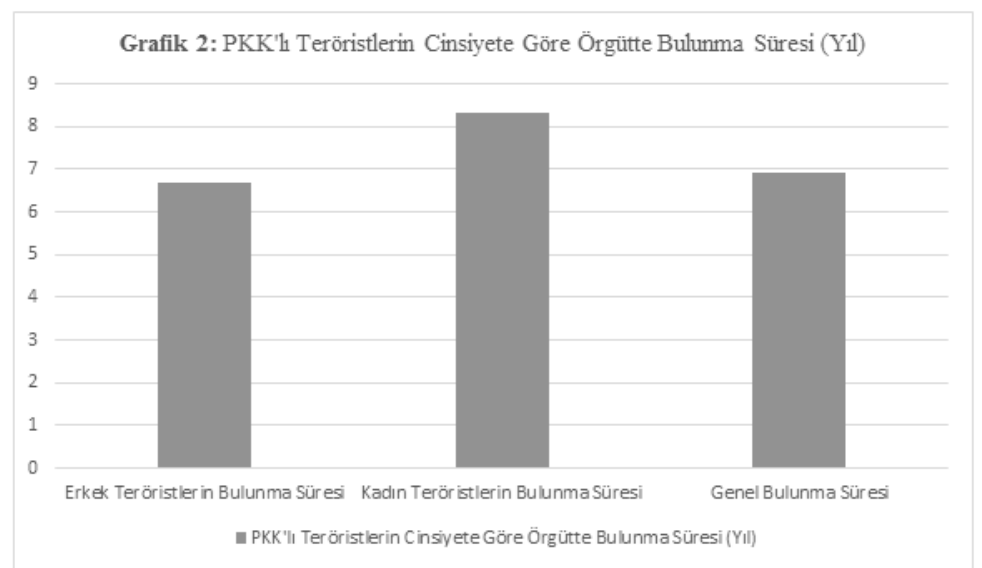

Kaynak: Nihat Ali Özcan ve Erdem Gürkaynak, "Kim Bu Dağdakiler”, TEPAV, 10 Şubat 2012, s. 49, https://www.tepav.org.tr/upload/files/13353504474.Kim_Bu_Dagdakiler.pdf, (Erişim Tarihi: 16.10.2020).

${ }^{18}$ Nihat Ali Özcan ve Erdem Gürkaynak, “Kim Bu Dağdakiler”, TEPAV, 10 Şubat 2012, s. 52, https://www.tepav.org.tr/upload/files/1335350447-4.Kim_Bu_Dagdakiler.pdf, (Erişim Tarihi: 16.10.2020). 
PKK'da Kadın Teröristlerin Rolü ve Örgüt İçi Cinsel İstismar

Örgüt içerisinde yer alan teröristlerin örgütte bulundukları y1l üzerine yapılan çalışmada kadınların örgütte bulunma süresi erkeklere göre daha uzundur. Kadınlar PKK içerisinde ortalama 8,3 yıl kalırken, erkek teröristler ise örgütte ortalama 6,7 y1l kalmaktadır. PKK' 1 teröristlerin örgüt içerisinde genel olarak bulunma süresi ise ortalama 6,9 yıldır. Bunun temel sebebi olarak kadın ve erkeklere örgüt içerisinde çoğunlukla farklı roller verilmesini ve bu teröristlerin örgüt içerisinde farklı amaçlarla kullanılmasını söyleyebiliriz.

PKK hem tarihsel süreçte hem de günümüzde kadınların birçok sebepten örgüt içerisinde yer almasını istemektedir. Kadınların PKK içerisinde tercih edilme sebepleri aşağıdaki tabloda verilmiştir:

\begin{tabular}{|c|}
\hline Tablo 1: PKK İçerisinde Kadın Teröristlerin Tercih Edilme Sebepleri \\
\hline Örgüt içi iktidarı elde tutma \\
\hline Bilgi toplama \\
\hline Propaganda faaliyetleri \\
\hline Örgüt içi disiplini sağlama \\
\hline Erkekleri eylemlere motive etme \\
\hline Erkeklerin örgütten kaçmalarını engelleme \\
\hline PKK'nın toplumsal tabana yayılmasını sağlama \\
\hline PKK'ya yeni elemanlar kazandırma \\
\hline Yeni bir ulus inşa sürecinde bir araç olarak kullanma \\
\hline
\end{tabular}

PKK içerisinde kadın teröristler çeşitli sebeplerden tercih edilmekte ve bu tercihlerin en belirgin özelliğinin ise örgüt içerisindeki düzeni sağlamaya yönelik olduğu görülmektedir. Terör örgütlerinde kadınların kullanılması üzerine literatürde yer alan yayınlarda olduğu gibi PKK içerisinde de kadınlara çoğunlukla ikincil rol verilmekte ve kadınlar, erkek teröristlerin örgütte tutulması için de birer yem olarak kullanılmaktadır.

\footnotetext{
${ }^{19}$ Alkan, a.g.e., s. 276.
}

\section{9}

Güvenlik Stratejileri

Cilt: 17

Say1: 37 
130

Güvenlik Stratejileri

Cilt: 17

Sayı: 37

PKK içerisinde kadınların tercih edilme sebeplerinin yanı sıra PKK içerisindeki kadın algısının süreç içerisinde değişime uğraması da örgütün yapısına etki etmiştir. Kadın teröristler PKK içerisinde örgütün ilk eylemlerini gerçekleştirdiği tarihten itibaren aktif bir şekilde katılım göstermemiş, zamanla hem örgütün kadın algısında yaşanan değişimle hem de kadınların PKK algısında yaşanan değişimle kadınlar isteyerek veya zorla PKK saflarına katılmıştır. Bu nedenle PKK'nın kadın algısının tarihsel süreç içerisinde nasıl bir değişime uğradığından bahsetmek gerekmektedir.

PKK'nın eylemlerinin başladığı tarihten uzun bir süre sonra kadınların örgüte katılmasında, Sovyetler Birliği'nin yıkılması ile sosyalizmin çöküşü ve bunun sonucunda Abdullah Öcalan'ın kadınların örgütteki varlığı ile ilgili söylemlerinin değişmesi yer almaktadır. PKK'nın kuruluşundan 1990'lı yıllara kadar, kadınların örgüt içerisinde yer alarak örgütün savaşma kabiliyetini azaltacağı yönünde bir görüş hâkimken, 1990'lardan itibaren Sovyetler Birliği'nin yıkılıp Marksist ideolojinin aileye yönelik olumsuz bakışının yumuşamasıyla PKK içerisinde de kadınlara yönelik algının değişmeye başladığı görülmektedir. ${ }^{20}$ Örgütün faaliyetlerine başladığı ilk yıllarda örgüt içinde kadınlara yönelik söylem “özgürleștirilecek köle-kadınlar” iken 1990’l1 yıllardan itibaren ise örgüt içerisinde kadına kutsallık içeren bir atıf yapılarak "özgürleştirilecek kadınlar, tanrıçalar” şeklinde değişmiştir. ${ }^{21}$ Örgütün kadın tanımlamasında yaşanan değişimin etkisiyle 8 Mart 1995 'te örgüt ilk kadın kongresini düzenlemiş ve sözde "Kürdistan Özgür Kadınlar Birliğì" kurulmuştur. Bu tarihten itibaren kadınların örgüt içerisinde aktif rol almasından dolayı bu tarih PKK tarafindan kadınların "özgürlük hareketlerinin” başlangıç tarihi olarak gösterilmiştir. ${ }^{22}$

${ }^{20}$ Nergiz Erdem, "Kadın Terörist Kimliğinin Psiko-Sosyal Kökenleri ve Sosyal Politikalar", Güvenlik Çalışmaları Dergisi, Aralık 2017, Cilt 19, Sayı 3, 8-26, s. 13.

${ }^{21}$ Handan Çağlayan, Analar, Yoldaşlar, Tanrıçalar: Kürt Hareketinde Kadınlar ve Kadın Kimliğinin Oluşumu, İletişim Yayınları, İstanbul, 2017, s. 100-101.

${ }^{22}$ Valentina Dean, "Kurdish Female Fighters: The Western Depiction of YPJ Combatants in Rojava", Glocalism: Journal of Culture, Politics and Innovation, 2019, Sayı 1, 1-29, s. 6, 
PKK'da kadın teröristlerin varlığı üzerine yapılmış sınıflandırmalarda örgüt, tarihsel olarak üç döneme ayrılmıştır. Örgütün kurulduğu 1978 yılından kadın teröristler için sözde "Kürdistan Yurtsever Kadınlar Birliği” ismiyle ayrı bir örgütlenmenin kurulduğu 1986 yılına kadarki süreç örgütün ilk dönemi olarak değerlendirilmektedir. İkinci dönem olarak 1986 yılından Öcalan'ın yakalandığı 1999 yılına kadarki süreç ele alınmaktadır. Örgütün üçüncü dönemi olarak ise 1999 yılından günümüze kadarki süreç kabul edilmektedir. ${ }^{23}$

Yapılan dönemsel sınıflandırmaya göre örgütün ilk döneminde örgüte katılan kadın sayısı oldukça az olmuştur. Bu dönemde ön plana çıkan kadın terörist ise terörist başı Öcalan ile ilişkisi bulunan Fatma kod adlı Kesire Yıldırım'dır. Örgüte ilk dönemde kadın katılımının az olmasının en önemli nedeni olarak Öcalan'ın Kesire Yıldırım ile yaşadığı problemler gösterilmiş ve bu problemler dolayısıyla Öcalan'ın kadınları "erkekleri düşüren, yozlaştıran" bir sorun olarak görmesi belirtilmiştir. Bu dönemde Öcalan'ın kadına bakış açısındaki olumsuzluğun yanı sıra; kadın teröristlerle yapılan mülakatlarda örgütün ilk döneminde katılım sağlayan kadınların Kesire Yıldırım tarafından psikolojik baskıya uğradığ 1 ve böylece kendisine alternatif olabilecek kadın teröristleri örgütten uzaklaştırdığı dile getirilmektedir. Söz konusu baskılar dolayısıyla da örgüte ilk dönemde kadın terörist katılımının az olduğu ifade edilmektedir. ${ }^{24}$

Örgütün ikinci dönemini oluşturan 1986-1999 yılları arasında ise Öcalan Kesire Yıldırım'dan ayrılmış ve Kesire Yıldırım örgüt tarafından "devletin ajanı" olarak nitelendirilmiştir. Böylece bu dönemde Öcalan tarafından, örgüt içerisinde yer alan kadın teröristler üzerine yeni bir tanımlama yapılmıştır. $\mathrm{Bu}$ dönemde örgütün kadın konusuna daha fazla eğilmesinin sebebi olarak da Sovyetler Birliği’nin çöküşü sonucu Marksist ideolojinin önemini yitirmesiyle kadın ve aile yapısı üzerine

https://glocalismjournal.org/wp-content/uploads/2019/05/Dean_gjcpi_2019_1.pdf, (Erişim Tarihi: 22.01.2020).

${ }^{23}$ Alkan, a.g.e., s. 77-91.

${ }^{24}$ A.g.e, s. 79-81. 
132

Güvenlik Stratejileri

Cilt: 17

Sayı: 37

geliştirilen söylemlerde yumuşamalar gerçekleşmesi gösterilebilir. $\mathrm{Bu}$ dönemde Öcalan, örgüte kadınların katılımını artırmak amacıyla daha önceki olumsuz söylemleri yerine kadınları "özgürlük" teması üzerinden tanımlamıştır. Kadınların kölelik hayatından kurtarılması ve özgürleştirilmesi söylemlerini kullanarak "özgürleşen kadın, özgürleşen [sözde] 'Kürdistandır' sloganını üretmiştir. ${ }^{25}$ Öncesinde örgütte erkeklerin kendilerini sakınması gereken tehlikeli varlıklar olarak görülen kadınlara, daha sonra sözde "Kürdistan'ın kurtarılması" için birlikte mücadele edilmesi gereken kişiler misyonu yüklenmiştir. ${ }^{26}$

1990'l y yllardan itibaren ise kadın teröristlerin örgüte aktif olarak katıldığı gözlenmiş ve böylece örgütün kadın söylemi de değişmiştir. 1990'lı yıllardan sonra yer alan örgüte ait metinlerde kadınların kötü olmadığından ve kadınlara güvenilmesi gerektiğinden bahsedilmektedir. Öcalan tarafından yapılan özgür ve güvenilir kadın tanımlaması, örgüt içerisindeki kadınlar için yeni bir tanım olarak gösterilmiştir. Daha öncesinde yapılan "köle kadın" tanımlamasında cinsiyetçi bir bakış açısıyla kadınlar, uzak durulması gereken varlıklar olarak tasvir edilmiştir. Ancak 1990'lı yıllardan itibaren yapılan yeni kadın tanımlaması yalnızca söylemsel açıdan daha pozitif bir imaja sahip olmakla birlikte kadının cinsel kimliği de söylem bazında ikinci plana atılmıştır. Yeni tanımlamada kadın, oldukça fazla fedakârlık yapması gereken ve fedakârlıklar sonucunda "tanrıça" haline gelecek bir varlık olarak ifade edilmiştir. ${ }^{27}$

1990 yılından itibaren PKK'nın kadın tanımlamasındaki değişim ile kadınların örgüte katılmasında ciddi bir artış yaşanmıştır. 1993 yılından itibaren sayıları önemli ölçüde artan kadınların oranı, bu tarihte örgütün üçte birine tekabül etmiştir. Kadınların örgüte en fazla katılım sağladığı yıl ise 1999 olmuştur. ${ }^{28}$ Aynı zamanda kadınların örgüte katılım oranının en yüksek olduğu yıllar olan 1992-1994 arası ise PKK'nın terör faaliyetlerini en üst seviyeye çıkardığ 1 yıllardır. Bu

\footnotetext{
${ }^{25}$ A.g.e., s. $82-83$.

${ }^{26}$ Çağlayan, a.g.e., s. $102-111$.

${ }^{27}$ Çağlayan, a.g.e., s. $112-118$.

${ }^{28}$ Alkan, a.g.e., s. 76.
} 
dönemde özellikle Doğu Anadolu ve Güneydoğu Anadolu bölgelerinde kadınların "özgürleşmek" propagandasına kapılarak örgüte katılması hızlanmıştır. Zira PKK, kadın teröristlerin çatışmalarda ölmesini de propaganda aracı olarak sıkça kullanmıştır. ${ }^{29}$

1999 sonrası süreçte terörist kadınlarla yapılan mülakatlarda, öncelikle Öcalan'ın yakalanmasının kadınlar üzerinde psikolojik bir çöküşe sebep olduğu ifade edilmiştir. Kadın teröristlerin doğrudan Öcalan'a bağlı örgütlenmelerinin olması ve talimatları da bizzat Öcalan'dan almaları, Öcalan'ın yakalanmasıyla kadın teröristlerde bir panik havası yaratmış ve kadınlara, örgüt içerisinde erkek teröristlerin büyük tepkileri ve engelleriyle karşılaşacaklarını düşündürmüştür. ${ }^{30}$ Öcalan'ın yakalanmasından sonra örgüt içerisindeki erkek teröristlerden tepki göreceklerinden emin olan kadınlardan "Zelal” kod adlı terörist o dönemki korkularını; "Bizim hepimizde şöyle bir psikoloji gelişmişsi. Erkekler bizi mahvedecek. (...) bundan sonra bizi karllarl yapacaklar, kendi metresi yapacaklar, istedikleri gibi bize yaklaşacaklar, o dönemin bütün intikamını alacaklar,"31 sözleriyle ifade etmiştir. Ancak kadın teröristlerle yapılan mülakatlarda, Öcalan'ın yakalanmasından önce de kadınların özgürleşmesi söyleminin gerçeklik payının olmadığı, aksine PKK'ya katılan kadınların diğer kadınlara göre daha köle gibi yaşadığı ifade edilmiştir:

“Aslında kadın özgürlüğü diye bir şey yapılmadı, PKK'deki kadın dışardakilere oranla çok daha köledir. Çünkü dünyaya ilişkin bir görüşü yoktur. Genel bir kültürü yoktur. Bütün dünyası ve bildiği A. Öcalan'dır. (...) Kendisi ‘bu parti kadın partisidir, ben erkekliğini öldürmüş bir kadın önderiyim' der ama aynı kadını bireysel hizmet ve isteklerinde çok rahat kullanmıştır. Bunu yaptığı zaman 'tabularınızı kırıyorum, tabuları olan kadın özgür değildir' değerlendirmesiyle gerekçeliyordu. Kısaca

\footnotetext{
29 A.g.e, s. 84-85.

${ }^{30}$ A.g.e, s. $88-89$.

31 A.g.e, s. 89.
}

\section{3}

Güvenlik Stratejileri

Cilt: 17

Say1: 37 
134

Güvenlik Stratejileri

Cilt: 17

Sayı: 37

PKK'deki kadın, toplumda, köyünde yaşayan kadından daha geridir diyorum." 32

Öcalan'ın yakalanmasının ardından örgütün kadın yapılanması örgütün genel yapısına bağlanmış ve kadınların sözde yönetim kadrolarındaki görevlere gelmeleri engellenmiştir. $\mathrm{Bu}$ süreçte de örgüt tarafindan yapılan kadın tanımlamalarında zamanla kadın teröristlerin yüceltildiği görülmektedir. Bu yüceltme Öcalan'ın yakalanmasından önce de olduğu gibi, yalnızca söylem düzeyinde gerçekleşmiş olması dolayısıyla örgüte daha fazla kadın teröristin katılımının sağlanması için yapılmış hamleler olarak değerlendirilebilir. Zira örgütteki kadın teröristlerle yapılan mülakatlarda ve teröristlerin itiraflarında örgütün kadınları özgürleştirmediğine, aksine kadınların daha fazla küçümsendiğine, değer görmediğine ve cinsel istismara uğradıklarına yönelik ifadeler yer almaktadır. Örgütün kadınlar üzerine söylemleri ve örgüt içerisinde kadınlara yönelik eylemleri arasında büyük bir tezat bulunduğunu fark eden kadınlardan örgütten kaçmak isteyenler yakalandığı takdirde hain ilan edilerek tecrit edilmiş ve hatta infaz edilenler de olmuştur. ${ }^{33}$

PKK'lı kadın teröristlerle yapılan mülakatlarda, Öcalan'in propagandasını yaptığı gibi örgüt içerisinde kadın-erkek eşitliğine dayalı bir yapının olmadığı görülmektedir. Zira örgütün sözde yönetim kadrosunda her ne kadar kadın teröristler yer alsa da kadınların, karar alıcı olarak yeterince güçlü bir pozisyonda olmadığı kadın teröristlerle yapılmış mülakatlarda karşımıza çıkmaktadır. Örneğin; Leyla isimli kadın terörist, "Karar alma süreçlerinde ağırlık daima erkeklerdeydi. Oylama yapılıyordu, erkekler daha kalabalık olduğu için onların dediği oluyordu",34 ifadelerini kullanarak kadınların örgütün sözde yönetim kadrosunda erkeklerden sayıca daha az olması dolayısıyla örgütte karar alıcı konumunda bulunmadıklarını belirtmiştir. Benzer şekilde

\footnotetext{
${ }^{32}$ Necdet Buldan, $P K K^{\prime}$ de Kadın Olmak, Doz Yayınları, İstanbul, 2004, s. 58-59.

${ }^{33}$ A.g.e, $90-91$

${ }^{34}$ Alkan, a.g.e., s. 236.
} 
PKK’da Kadın Teröristlerin Rolü ve Örgüt İçi Cinsel İstismar

Çiğdem isimli kadın terörist de 2008 yılında kendisiyle yapılmış mülakatta şu sözleri kullanarak örgütün sözde yönetiminde kadınların konumu hakkında birtakım çıkarımlarda bulunmuştur:

"Ben örgütten ayrıldığımda kadınlar konseyde erkeklerle hemen hemen eşit düzeyde temsil ediliyorlard. Üst düzeyin bazen üçte ikisinin kadın olduğu zamanlar oldu. Neden eşit düzeyde bir temsil çabası vardı bunu hep düşünmüşümdür. Bunu yapıdan ayrıldıktan sonra daha iyi anlayabildim. PKK kadınları örgütte tutmak istiyordu. Çünkü kadınların örgütten ayrılması erkeklerin de örgütten kopuşunu hızlandırıyordu. Ancak bu temsil düzeyine rağmen karar alma süreçlerinde kadınlar yoktu. Çünkü yine kararı erkekler veriyordu. Murat Karayılan, Cemil Bayık ve Duran Kalkan veriyordu. Kadınların durumu göstermelik ve sembolik bir durumdu." 35

Örgüt içerisinde kadın-erkek eşitsizliğinin yanı sıra, kadınlar arasında da bir hiyerarşi mevcut bulunmaktadır. Bizzat Öcalan tarafindan bu hiyerarşi oluşturulmuş ve söz konusu hiyerarşik yap1 dolayısıyla örgüt içerisindeki kadınlar arasında da problemler yaşanmıştır. "Neval" kod adlı kadın terörist tarafindan yapılan açıklamada Öcalan hakkında övgü dolu sözler yazan kadınların, herhangi bir silahlı çatışmaya girmese de veya herhangi bir tecrübesi/yetkinliği olmasa da örgütün sözde yönetim kadrosu içerisinde yer aldığından söz edilmiş ve örgüt içerisinde kadınlar arasında dahi bir eşitliğin söz konusu olmadığından bahsedilmiştir. ${ }^{36} \mathrm{Bu}$ konuda "Hevi" kod adlı terörist ise örgüt içerisindeki hiyerarşik ve eşitsizliğe dayanan yapıyı şu sözlerle ifade etmiştir:

"Dağda [sözde] yönetim kadrosundaki bayanların kişisel eşyaları, özel yaşantıları vardı. İlk hayal kırıklı̆̆ını onları görünce yaşadım da diyebilirim. Örneğin, (...) gittiğimiz yerde sadece taşlar var. Tek bir ağaç, tek bir gölgelik yok. Güya kadın konferansı yapılıyor, tüm bayanların yüzü güneşten kavrulmuş,

\footnotetext{
${ }^{35}$ A.g.e, s. 237.

${ }^{36}$ Buldan, a.g.e., s. 35 .
}

\section{5}

Güvenlik Stratejileri

Cilt: 17

Say1: 37 
136

Güvenlik Stratejileri

Cilt: 17

Sayı: 37

yanmış, yara olmuş. O kızgın güneşin altında yemek yapıyorlar, ekmek pişiriyorlar, güneşten mahvolmuşlar. Ama yönetimdeki bayanlar için çadırlar açılmış, gölgelikler yapılmış. Dağda bulunması çok zor olan kremleri, kınaları var. Elleri sıcak sudan soğuk suya değmiyor, güvenlikleri (korumaları) var. Banyo suları bile güvenlikteki arkadaşlar tarafından getiriliyor." ${ }^{\text {37 }}$

Benzer şekilde Pelin isimli bir başka kadın terörist ise Öcalan'ın kadınlar karşısında kendisini kutsallaştırdığını ve kadınların kandırılıp bu söylemlere inandırılarak adeta kendisine tapındığını belirtmiştir. Hatta bu tapınmayı meşrulaştırmak amaciyla terörist başının "ben erkek değilim, beni karşınızda bir cins olarak görmeyin” ifadesini kullandığını belirtmektedir. Örgüt içerisinde bunları kadınların sorgulayamadığını dile getiren kadın terörist, aynı zamanda örgütteki kadın teröristler arasındaki eşitsizliği kast sistemine benzeterek her kadına aynı değerin verilmediğini ${ }^{38}$ şu sözlerle ifade etmiştir:

"Öcalan çirkin kadını sevmiyordu. Biçime ve fiziğe müthiş önem veren bir insand. Devrimci ve savaşan bir ortamda bence kafadaki güzelliklere ve devrimci becerilere önem vermesi gerekiyordu. Oysa lise mezunu, üniversite mezunu fiziği güzel olanlara, canım-cicim dediğinde gevşeyenlere ve çok seçici yaklaşıyordu kadınlara. Ön safta olan güzellikti (...) Yoğunlaşma evlerinde [Öcalan'ın Suriye'de olduğu dönemde 'özel eğitim' amacıyla kadınlardan seçtiği kişileri yanına alarak 'eğittiği' evler] neden hep güzel bayanların kaldığını sanıyorsunuz? Birlikte çekilen fotoğraflar var, havuzlarda çekilen fotoğraflar var. Biz dağda acımızdan ölürken saraylarda yaşıyordu." 39

Öcalan'ın kadın teröristler konusunda güzelliğe oldukça düşkün olduğu kendisinin ifadelerinde de yer almaktadır. Öcalan'ın kadınlara yönelik sözleri incelendiğinde kadın teröristlerin örgüte katılımında

\footnotetext{
${ }^{37}$ A.g.e, s. $80-81$.

${ }^{38}$ A.g.e, s. $45-46$

${ }^{39}$ A.g.e, s. $45-46$.
} 
güzellik ölçütünün oldukça önemli olduğu görülmektedir. "Çirkinleri saflarımıza almamak lazım. Kim alıyor bunları? Bizim için güzellik ölçüsü; fiziksel, düşünsel, zekâ yönünden güzel olmalıdır. "*0 Öcalan'ın PKK'lı kadın teröristlere yönelik söz konusu açıklamalarından yola çıkarak kadınların hem Öcalan hem de örgüt tarafindan birer meta olarak görüldüğünü ve kadın teröristlere de çoğunlukla güzellik ölçüsünde roller verildiğini söylemek mümkündür.

PKK içerisinde kadınların konumu incelendiğinde; kadın-erkek eşitsizliğinin yanı sıra kadınlar arasında da ciddi bir hiyerarşi bulunduğu, bu hiyerarşi dolayısıyla da örgüt içerisindeki kadınların dahi eşit olmadığı ve sözde yönetim kadrosu tarafından da eşit görülmediği ifade edilebilir. Aynı zamanda kadınların örgüte katılarak özgürleşeceği söylemi hem Öcalan hem de örgüt tarafından sıklıkla kullanılmasına rağmen; kadınlara örgüt içerisinde daha çok ikincil roller verilmiştir. Örgütün sözde yönetim kadrosunda da birçok kadın teröristin bulunması, örgütte kadınların karar alıcı konumunda yer almasına katkıda bulunmamakta, hatta örgüte katılan kadınların fiziksel güzelliğine önem verilerek bu güzelliğe göre kadınlar statü elde etmektedir. Bunların yanı sıra; diğer terör örgütlerinde olduğu gibi PKK'da da kadın teröristler ikincil rollerin yanı sıra özellikle intihar saldırılarında sıkça kullanılmaktadır.

\subsection{PKK'nın Intihar Saldırılarında Kadınlar}

Kadınların örgüt içerisinde hem eylemlerde hem de örgüt propagandası yapma amacıyla kullanıldığı görülmektedir. Özellikle intihar saldırılarında ve kendini yakma eylemlerinde yer alan kadınlar, PKK'nın sembolü haline getirilerek Doğu Anadolu ve Güneydoğu Anadolu Bölgelerinde yerel halkı etkileyerek örgüte terörist devşirme amacıyla hareket etmektedirler. Zira Emniyet Genel Müdürlüğü Terörle Mücadele Dairesi Başkanlığı tarafından hazırlanan raporda, 1996-2010 yılları arasında PKK'lı kadın teröristlerin intihar saldırılarına katılım

\footnotetext{
${ }^{40}$ Aytekin Yılmaz, Son Diktatör, Vadi Yayınları, İstanbul, 2020, s. 146.
} 
138

Güvenlik Stratejileri

Cilt: 17

Sayı: 37

oranının yüzde 55 olduğu belirtilmektedir. ${ }^{41}$ PKK içerisindeki kadın teröristlerin oranının yüzde 12 civarında olduğu göz önünde bulundurulacak olursa kadın teröristlerin böyle yüksek bir oranda intihar saldırılarında kullanılma sebepleri 7 maddede açıklanmıştır. Bu maddeler aşağıdaki tabloda verilmiştir:

\begin{tabular}{|c|} 
Tablo 2: PKK'lı Kadın Teröristlerin \\
İntihar Saldırılarında Kullanılma Sebepleri" \\
İlk yıllarda örgüte hâkim olan eril zihniyetin, \\
$\begin{array}{c}\text { kadınları bir güç olarak görmemesi nedeniyle, kadınların kendilerini } \\
\text { erkeklere karşı ispat etme arayışı içerisinde olması, }\end{array}$ \\
\hline $\begin{array}{c}\text { Kadınların erkeklere göre daha duygusal olmaları } \\
\text { ve örgütün bu duygusalığı değerlendirmesi, }\end{array}$ \\
\hline Kadınların erkeklere göre Abdullah Öcalan'a daha çok bağlı olmaları, \\
\hline $\begin{array}{c}\text { İntihar eylemleri sonrasında kadınların örgüt içerisinde } \\
\text { "tanrıçalar” olarak yüceltilmesi, }\end{array}$ \\
\hline $\begin{array}{c}\text { Örgütün kadınlara karşı güvenlik güçlerinin aramalarında } \\
\text { gelenek ve göreneklerden kaynaklanan nedenlerle } \\
\text { müsamaha gösterdiğinin farkında olması, }\end{array}$ \\
\hline $\begin{array}{c}\text { Bombaların hamilelik süsü verilerek kadınların üzerinde } \\
\text { daha kolay kamufle edilebiliyor olması, }\end{array}$ \\
\hline $\begin{array}{c}\text { Kadınların şehirlerde makyaj yaparak, saçlarını boyayarak ya da kısaltarak, } \\
\text { yerine göre açık ya da kapalı kıyafetler giyerek } \\
\text { kendilerini deşifre olmaktan koruyabilmesi. }\end{array}$ \\
\hline
\end{tabular}

Kadınların terör örgütlerinin intihar saldırılarında kullanılmasına ilişkin literatürde yer alan nedenlerin PKK için de geçerli olduğu görülmektedir. Tüm bunlara ek olarak PKK'lı kadınların intihar saldırılarında yer almasının başka sebepleri de bulunmaktadır. Özellikle örgüt içerisinde ataerkil zihniyet yapısının bulunması ve kadınların erkekler tarafindan aşağı görülmesi dolayısıyla kadınlar, kendilerini

\footnotetext{
${ }^{41}$ Alkan, a.g.e., s. 71.

${ }^{42}$ A.g.e, s. 229.
} 
erkeklere ispatlama ihtiyacı hissetmektedir. Bunun haricinde kadınlar, örgüt içerisinde Öcalan'ın, kadınları "tanrıçalaştıran" söylemleri, ayrı örgütlenmelere sahip olmaları ve örgütteki erkek teröristlerden ayrı tutulmaları dolayısıyla da terörist başı Öcalan'a karşı daha güçlü bir şekilde bağlıdırlar. Böylece herhangi bir emir geldiği takdirde erkeklere oranla kadınlar, intihar saldırılarında yer almaya daha yatkın görünmektedir.

1999 yılından itibaren Öcalan'ın yakalanmasıyla örgüt içerisinde kadın teröristlerin kendini yakma ve intihar saldırılarına katılma oranı oldukça hızlı bir şekilde yükselmiştir. İntihar bombacıları, PKK tarafından eylemler gerçekleştirilirken sağlanan stratejik kolaylıklar dolayısıyla sıklıkla kullanılmaktadır. Özellikle örgütün faaliyet alanlarının k1sitlandığı ve yeniden bir kitle desteğine ihtiyaç duyduğu bir dönemde PKK, kadınları ilk kez intihar bombacısı olarak kullanmaya başlamıştır.

Türkiye'de ilk intihar saldırısını gerçekleştiren kadın terörist “Zilan” kod adlı Zeynep Kınac1, 30 Haziran 1996 tarihinde Tunceli'de askeri tören esnasında gerçekleştirdiği intihar saldırısı ile 29 askerin yaralanmasına ve 8 askerin şehit olmasına sebep olmuştur. Kadın teröristin askeri tören alanına karnına bağladığı patlayıcılarla kendisine hamile kadın imajı vererek girdiği tespit edilmiştir. Zilan kod adlı teröristin, başta Öcalan olmak üzere örgüt tarafindan "kahraman" olduğu iddia edilmiştir. Öcalan şu sözleri kullanarak Zilan kod adlı teröristin intihar saldırısını kahramanlaştırmakta ve örgüt içerisindeki kadın teröristlere Zilan'ı örnek göstermektedir:

"Dönüşmeyen kişilik ikiyüzlüdür. Ateşle barutu bir arada tutarız ama sistemin kalbinde patlatırı. Zilan, bombasını sistemin beyninde patlattı. (...) Başka türlüsü de olmaz. Devrimci çalışmaları sevmeliyiz. Kendinizi hemen her zaman terbiye edin."

PKK'lı kadın teröristler ve PKK sempatizanları tarafindan övgüyle bahsedilen ve adeta "rol model" haline gelen Zilan kod adlı terörist adına Diyarbakır' da sözde anma törenleri dahi düzenlenmiştir. Zira Sebahat Tuncel, 2011 y1lında gerçekleşen sözde anma törenlerinden

\footnotetext{
${ }^{43}$ Y1lmaz a.g.e., s. $144-146$.
}

\section{9}

Güvenlik Stratejileri

Cilt: 17

Say1: 37 
140

Güvenlik Stratejileri

Cilt: 17

Sayı: 37

birinde; Zilan kod adlı intihar bombacısı teröristi hem Türk devleti karşısında "kahramanlaştırmak" istemiş hem de söz konusu terör eylemlerinin amacının yalnızca devlet sistemi olmadığını, aynı zamanda feminizme vurgu yaparak kadın özgürlüğünü sağlama amac1 taşıdığını da iddia etmiştir. ${ }^{44}$

Kadın intihar bombacılar tarafından yapılan eylemlerin niçin son yıllarda daha sik bir şekilde tercih edildiği konusunda yapılan araştırmalara atıfla, söz konusu teröristlerin bir kahraman gibi gösterilerek örgüt propagandasının yapıldığı ve böylece örgüt içerisindeki teröristleri daha çok psikolojik olarak etkilemeye yönelik söylemlerde bulunduğu söylenebilir. Zira örgütün yapmış olduğu bu "kahraman kadın" propagandalarına birçok kadın inanmış ve örgüte katılmıștır. Üniversite ikinci sınıfta okurken örgüte katılan "Zinarin" kod adlı terörist, PKK tarafından sembolleștirilen kişilerden biri olan Beritan isimli kadın teröristten etkilenerek örgüte katıldığını şu sözlerle ifade etmiştir:

“(...) Ben Beritan'dan çok etkilenmiştim örgüte girmeden önce. Örgüt o zaman gazetelerde, dergilerde Beritan'ın resmini, silahlı resmini, işte onun hayat hikayesini, o dönemdeki gazete ve dergilerde boy boy yayınlanmıştı. Onun hikayesini okudukça PKK'ya katılma kararlılı̆̆ım artt1."

Örgütün genç kızları ve kadınları devşirme konusunda çatışmalarda ölen ve intihar saldırıları gerçekleştiren kadınları rol model göstererek sembolleştirmesi, kadınların terör örgütüne katılımında oldukça önemli bir rol oynamıştır. PKK'nın özellikle Öcalan'ın yakalanmasının ardından hızlandırmış olduğu bu strateji, yalnızca Doğu Anadolu ve Güneydoğu Anadolu Bölgelerinden değil aynı zamanda batıdaki büyük şehirlerden de PKK'ya kadınların katılımını büyük ölçüde artırmıştır.

44 "Sebahat Tuncel İntihar Bombacisını Övdü”, NTV, 1 Temmuz 2011, https://www.ntv.com.tr/turkiye/sebahat-tuncel-intihar-bombacisini-ovdu,qeC-UAv0dU2b EsQKWKOZcQ, (Erişim Tarihi: 21.08.2020).

${ }^{45}$ Alkan, a.g.e., s. 179. 
PKK'da Kadın Teröristlerin Rolü ve Örgüt İçi Cinsel İstismar

\subsection{PKK’lı Kadın Teröristlere Yönelik Cinsel İstismar}

Kadın teröristlerin örgüte katılırken içerisinde bulunduğu kadınerkek eşitliğinin sağlanması, ataerkil düzene yönelik eleştiriler, sistemi değiştirerek özgürleşme gibi beklentilerinin aksine kadınlar örgüt içerisinde özgürleşmemiş, tarihsel süreç içerisinde sürekli olarak istismar edilmiştir. Öcalan ve örgütte sözde yönetim kadrosunda yer alan kişiler tarafından sıkça dile getirilen "kadının özgürleşmesi" söylemlerinin gerçeği yansıtmadığı ve örgüt içerisinde kadınların istismar edildiği yapılan araştırmalarda ve özellikle örgütten kaçarak teslim olan teröristlerin itiraflarında açıkça görülmüş̧ür.

Öcalan, kadınları tanımlarken oldukça olumlu ifadeler kullanmış ve sözde “Kürdistan'ın” özgürlüğünü kadınların özgürlüğü ile bağdaştırmıştır. Kadınları söylemleriyle "tanrıçalaştıran" PKK içerisinde kadın ve erkek teröristler arasında yaşanabilecek her türlü duygusal ilişki yasaklanmıştır. Sevgi ve aşk gibi kavramlar yeniden tanımlanarak bu kavramlar örgüt, propaganda, örgütlenme gibi kavramlarla ilişkilendirilmiştir. Böylece örgüt içerisinde kadın ve erkek arasındaki duygusal ilişkilerin önüne geçilmek istenmiş ve duygusal ilişkiler örgütten ayrılan militanların sayısını artırdığı, örgütün çatışma kapasitesini azalttığı ve örgüt içerisinde yozlaşmaya neden olduğu gerekçesiyle yasaklanmıştır. Öcalan, kadın-erkek arasında oluşabilecek duygusal ilişkiyi engellemek amacıyla yalnızca kadınlara karşı "özgürlük" söylemini kullanmamış, aynı zamanda erkeklere de bu konuda birtakım zorunluluklar getirmiştir. Terörist başı Öcalan, erkeklerin "parti içerisinde devrimci olmayan duygularını terbiye etmeyi" amaçladığını ve bu nedenle de erkeklerin "içindeki erkeği öldürmesi gerektiğini" dile getirmiştir. Örgütün özgürlük tanımlaması kadın ve erkek teröristler için değişmekte ve kadınlar "tabularını yıkmadıkça" özgürleşemezken, erkeklerin de "içlerindeki erkeği öldürmedikçe” özgürleşemeyeceği belirtilmiştir. ${ }^{46}$

Öcalan'ın yakalanmasının ardından Temmuz 2003'te gerçekleştirilen bir toplantıda, terör örgütü PKK'nın sözde yönetim kadrosunda yer alan

\footnotetext{
${ }^{46}$ Y1lmaz, a.g.e., s. 47.
} 
142 Osman Öcalan'ın da onayıyla örgüt içerisinde ilişki ve "evlilik"47

Güvenlik Stratejileri

Cilt: 17

Say1: 37 serbestliği getirilmiştir. Bu kararın ardından örgüt içerisinde birçok terörist evlenmiş veya nişanlanmış, hatta bu durumun örgütü yozlaştırmaya sebep olduğu yönünde örgüt içerisinden eleştiriler de yapılmıştır. Söz konusu serbestliğin eleştirilerle karşılaşmasının ardından sözde kongre yapılmış ve bu kongrede sözde seçim yapılarak kadınerkek ilişkilerinin serbest olması gerektiğini savunan Osman Öcalan ve ekibi tasfiye edilmiştir. Böylece yeniden PKK içerisinde kadın-erkek ilişkileri sınırlandırılmaya başlanmıştır. ${ }^{48}$

Öcalan'ın PKK içerisinde kadın-erkek ilişkilerine yönelik yapmış olduğu bu sınırlandırmaya yalnızca erkek teröristler arasından değil, kadın teröristler arasından da karşı çıkanlar bulunmuştur. "Bese" kod adlı kadın terörist, örgüt içerisinde cinsel ilişki konusunda çifte standart olduğundan bahsetmiş ve "sözde örgütte cinsel ilişsi yasaktt, fakat bu yasak ne hikmetse üst düzey yönetim için geçerli değildi" sözlerini kullanırken "Ejin" kod adlı terörist de terörist başı Öcalan ve örgütün sözde yönetim kadrosunda yer alan Murat Karayılan, Cemil Bayık, Duran Kalkan ve Bahoz Erdal gibi teröristlere cinsel ilişkinin serbest olmasına rağmen kadın teröristler için yasak olduğunu dile getirmiştir. ${ }^{49}$ Aynı zamanda örgüt içerisinde kadın-erkek ilişkileri konusunda daima kadınların haksız olduğu yönünde bir anlayışın hâkim olduğundan da bahsedilmiştir. Böylece kadın-erkek ilişkilerindeki yasaklar ve katı uygulamalar nedeniyle kadın teröristler arasında eşcinsel ilişkilerin de gizli bir şekilde artış gösterdiği teröristlerle yapılan mülakatlarda belirtilmiştir. ${ }^{50}$

Kadın-erkek ilişkilerine yönelik söz konusu yasaklamalar örgütü korumak ve kadını özgür kılmak söylemleriyle yapılmıssa da kadınların,

${ }^{47}$ Örgüt içerisinde kadın ve erkek teröristlerin, örgütün sözde üst düzey yönetimi ile görüşerek evlendiklerini beyan etmesiyle söz konusu evlilikler gerçekleşmiştir. (Alkan, a.g.e., s. 251.

48 A.g.e, s. $251-253$.

${ }^{49}$ A.g.e, s. 255.

${ }^{50}$ A.g.e, s. 256. 
örgüt içerisinde tecavüze ve cinsel istismara sık sık maruz kaldıkları ortaya çıkmaktadır. Söz konusu istismarların genellikle örgütün sözde yöneticileri tarafindan yapılması da örgütün propagandaları ile eylemlerinin arasında büyük bir tutarsızlık olduğunu gözler önüne sermektedir. Hâlbuki Öcalan, kadın tanımlamasını yaparken radikal feminist söylemler kullansa da Öcalan ve örgütün pratikte kadınları cinsel köle olarak kullandığı örgütten kaçarak teslim olan teröristlerin itiraflarında yer almaktadır. ${ }^{5}$

Terör örgütlerinde kadınların önemli rollerinden biri olan, erkek teröristleri örgüte bağlamak görevi $P K K$ 'da da benzer şekilde uygulanmaktadır. Kadın teröristler üzerinden gerçekleştirilen bir cinsel sömürü ile erkek teröristlerin örgüte olan bağlılıklarının artırıldığı, kadın teröristlerle yapılan mülakatlarda yer bulmaktadır. 1996 yılında örgüte katılan “Aryen” kod adlı terörist, Öcalan'ın kadın teröristlerin birçok erkekle flört etmesi gerektiğini dile getirerek erkeklerin örgüt içerisinde bağlılıklarının artırılmasına atıf yaptığını belirtmiştir. ${ }^{52}$ Böylece erkeklerin kadınlara bağlı olması ve kadınların da yalnızca Öcalan'a bağlı olmaları sebebiyle kadınların, erkeklerle Öcalan arasında bir köprü görevi görmesi istenmiştir.

Öcalan'ın söylemlerinde "özgürleştirilecek kadınlar-tanrıçalar" olarak yer bulan kadın teröristler, PKK içerisinde Öcalan da dâhil olmak üzere erkek teröristlerin tecavüzüne ve cinsel istismarına maruz kalmaktadır. Erken yaşta istenmeyen evlilik, aileler tarafindan kız çocuklarının okula gönderilmemesi, aile içi şiddet ve baskı gibi genellikle psikolojik ve sosyolojik temelli nedenlerle örgüte katılan kadınlar, özellikle örgüt tarafından 1990'lı yıllardan itibaren sıkça kullanılan "özgürleşen kadın, özgürleşen [sözde] 'Kürdistan'dır" söyleminden etkilenerek PKK'yı bir "kaçış yolu" veya "umut" olarak görmüşlerdir. Kadın teröristlerle yapılan mülakatlardan birinde Melis adlı bir kadın terörist, şu sözlerle örgütün özgürlük söyleminden

\footnotetext{
51 A.g.e, s. 253.

52 Buldan, a.g.e, s. 66.
}

\section{3}

Güvenlik Stratejileri

Cilt: 17

Say1: 37 
144

Güvenlik Stratejileri

Cilt: 17

Sayı: 37

etkilenerek katıldığ $ı n ı$ ve kandırıldığını ifade etmiştir:

“(...) $\mathrm{O}$ anda düşünün işte dağda kadınlar, ellerinde silah var öldürüyorlar. $\mathrm{O}$ dönem bu propaganda çok yapıldı. Ve bu ister istemez kadını dağa yöneltti. $\mathrm{O}$ toplumsal yapı gerçekliğinde bunun propagandası çok yapıldı. Benim katıldığım dönemde bu propagandalar bana çok yapıldı. Mesela kadınlar özgür. Kadınlarla erkekler arasındaki ilişkiler tamamıyla eşittir. Hiçbir sorun yok. Aslında melek insanlar yani. Hiç olumsuz yaklaşım yok, melek gibi yani. Kadınlar bu propagandaya inandı, inandırıldılar." ${ }^{, 53}$

Kadın teröristin ifadelerinde de yer bulduğu şekliyle kadınların çoğunlukla toplumsal baskılardan ve kadın-erkek arasındaki eşitsiz ilişki yapısından kaçmak amacıyla örgüt propagandalarından etkilendiklerinden söz edilmektedir. PKK yerel halkı etkilemek amacıyla, örgüt içerisinde kadının önemli ve güçlü bir konumda olduğu algısı oluşturarak örgüte eleman devşirmeyi hedeflemiştir. Ancak kadın-erkek eşitliği gibi sebeplerden örgüte katılan kadınlar, cinsel istismar ve tecavüzlerle karşılaşmış ve örgütün söylemleriyle faaliyetleri arasında zıtlık olduğunu idrak edebilmiştir.

Kadın teröristlerle yapılan mülakatlarda, örgüte katılan kadınların yüzde 90'ının örgütün “tecavüz üssü” haline gelen Kandil'e götürüldükten sonra ilk 30 gün içerisinde erkek teröristler tarafından tecavüze uğradığı belirtilmiştir. ${ }^{54}$ Tecavüzcülerin hiçbir şekilde cezalandırılmamasına rağmen kadınların ise şikâyet ettikleri takdirde tecrit veya infaz ile cezalandırıldığı anlatılmaktadır. Sara Kanireş isimli teröristin PKK'nın kadın yapılanmasının başındaki teröriste, "bizi seks kölesi olarak kullaniyorlar" şikâyetinin ardından örgütteki tüm kadınların aynı şeyleri yaşadığı dile getirilmiş ve örgüt içerisinde

${ }_{53}^{53}$ Alkan, a.g.e., s. 178.

54 “PKK'nın 'Tecavüz Üssü’ Kandil! Kadın Terörist PKK'nın Kirli Yüzünü Anlattı”, Sabah, 9 Kasim 2019, https://www.sabah.com.tr/gundem/2019/11/09/pkknin-tecavuzussu-kandil-kadin-terorist-pkknin-kirli-yuzunu-anlatti, (Erişim Tarihi: 12.09.2020). 
Özgürleştirilme ifadesi kullanılarak özellikle Öcalan tarafından kadınların "yoğunlaşma evlerinde" defalarca tecavüze ve şiddete maruz kaldığı terörist ifadelerinde yer almaktadır. "Dilaram" kod adlı kadın teröristin örgütte kendisinin ve hemcinslerinin yaşadıkları cinsel istismarı ve şiddeti anlatmak amacıyla yazmak istediği kitabı için diğer kadın teröristlerle yapmış olduğu mülakatlarda da söz konusu istismar açıkça görülmektedir. Özellikle örgüt içerisinde kadınlar arasındaki hiyerarşinin bu cinsel istismar çerçevesinde şekillendiği ve kadınların bu şekilde "rütbe" aldığı görülmektedir. Bu mülakatlardan birinde Öcalan'ın "yoğunlaşma evlerine" genç ve güzel kadınların alındığı belirtilmiştir. Burada Öcalan'ın kadınlara "özel eğitim” adı altında tecavüz edip şiddet uyguladığ 1 ifade edilmektedir. Şam'da bulunan yoğunlaşma evinde kalan kadın teröristlerden biri, kendisine tecavüz etmeye yeltenen Öcalan'a karşı çıktığı için “özgürleştirilmeyi reddettiği” gerekçesiyle Öcalan tarafından dayak yemiştir. Aynı evde kalan diğer kadınlar tarafindan da tecavüze ses çıkarmaması için "hazırlanmıştır". "Başkan bizi özgürleştiriyor. Sen özgürleşmek istemiyor musun? Başkana erkek gözüyle baklyorsun. O başkan, o zincirlerimizi kıran bir peygamber ${ }^{15657}$ sözleriyle karşılaşan kadın terörist, Öcalan tarafindan yapılan tecavüzlere sesini çıkarmaktan korkmuştur. Aynı zamanda Öcalan'ın evinde kalan kadınlara "Benim yetiştirdiğim kadınlar, hiçbir erkekle ilişkiye girmemeli, sonuna kadar bana bağlı kalmalı" sözlerini kullanarak kadınları tehdit ettiğini belirten terörist, dağda başka erkeklerle ilişkiye girerek Öcalan'dan intikam almak istediğini ve Öcalan'ın "özel eğitim”

\footnotetext{
55 “PKK Örgütü Dosyası: Bin 150 Kadın İtirafçıdan PKK'nın Tecavüz ve İnfazları”, Özel Büro Istihbarat Grubu, https://www.ozelburoistihbarat.com/teror/pkk-orgutu-dosyasi-bin150-kadin-itirafcidan-pkknin-tecavuz-ve-infazlari-9129, (Erişim Tarihi: 12.09.2020).

56 Alıntılanan metin, makale yazarlarının ve Güvenlik Stratejileri Dergisi'nin görüşlerini yansıtmamakta, yalnızca makalenin argümanını desteklemek ve örgütün kadınları nasıl kandırdığını belirtmek amacıyla kullanılmaktadır.

57 “Kandil Dağı'ndan Yaşanmış Tecavüz Hikayeleri”, Hürriyet, 5 Şubat 2006, https://www.hurriyet.com.tr/kelebek/kandil-dagi-ndan-yasanmis-tecavuz-hikayeleri3886942, (Erişim Tarihi: 12.09.2020).
}

\section{5}

Güvenlik Stratejileri

Cilt: 17

Say1: 37 
146

Güvenlik Stratejileri

Cilt: 17

Sayı: 37

adı altında kendisine tecavüz ettiği ve şiddet uyguladığ 1 için de rütbesi olması dolayısıyla söz konusu ilişkileri nedeniyle infaz edilmediğini dile getirmiştir. ${ }^{58}$

Öcalan'ın “yoğunlaşma evlerinde" tutulan kadınların örgüt içerisinde rütbe almasının yanı sıra, örgütün sözde üst düzey diğer yöneticileri tarafından da kadın teröristlerin sık sık tecavüze uğradığı terörist ifadelerine yansımıştır. Hatta söz konusu açıklamalardan, örgüt içerisinde kadın teröristlere yapılan tecavüzlerin ve cinsel istismarın bir hak olarak görüldüğü anlaşılmaktadır. Zira birçok kadın terörist, tecavüze uğradıktan sonra yaşamış oldukları travmayı kaldıramayarak örgütten kaçmaya çalışmış, kaçamayanlar da intihar etmiştir. Örneğin; "Dilan" kod adlı terörist, PKK'nın sözde yönetim kadrosunda yer alan terörist Murat Karayılan'ın tecavüzüne uğradıktan sonra el bombasıyla intihar etmiştir. ${ }^{59}$ PKK'dan kaçarak teslim olan "Amara Digor" kod adlı terörist; Duran Kalkan ve Murat Karayılan gibi örgütün sözde yönetim kadrosunda bulunan teröristler tarafindan istismara uğradığ 1 konusunda şikâyetçi olan kadınların kamplarda PKK tarafından oluşturulan sözde mahkemelere çıkarılarak ajanlıkla, iftira atmakla ve hatta yalan söylemekle suçlanarak infaz edildiğini ifade etmiştir. ${ }^{60}$

Özellikle örgütün sözde üst düzey yönetimindeki teröristler tarafından tecavüze uğrayan kadın teröristler, şikâyet ettikleri takdirde infazla cezalandırıldıkları için genellikle örgütten kaçmaya çalışmaktadır. Ancak yakalandıkları takdirde aynı şekilde infaz edilecekleri için yakalandıklarında intihar etmeyi tercih etmektedir. PKK'ya kadın teröristlerin katılımının gerçekleştiği tarihlerden itibaren s1k s1k yaşanan bu hadiselerde erkek teröristlere -özellikle sözde üst düzey yönetimde yer alanlara- örgütün herhangi bir yaptırım uygulamamasına

\footnotetext{
${ }^{58}$ A.g.e.

59 "PKK Elebaşı Karayılan'ın Tecavüz Ettiği Kadın Terörist El Bombasıyla Kendini Patlattı", Haberler.com, 10 Ağustos 2018, https://www.haberler.com/pkk-elebasikarayilan-in-tecavuz-ettigi-kadin-11132995-haberi/, (Erişim Tarihi: 12.09.2020).

60 “İşte PKK'daki Tecavüz Dehşetinin Belgesi! Duran Kalkan'ın Video Kaydını Verdi....", Takvim, 22 Kasım 2019.
} 
PKK’da Kadın Teröristlerin Rolü ve Örgüt İçi Cinsel İstismar

rağmen; cinsel istismara uğrayan kadın teröristlerin cezalandırılması ve infaz edilmesi kadın teröristlerin intiharı tercih etmesine sebep olmaktadır. Bu hadiselerden biri de "Mardinli Rojin" kod adlı bir teröristin Suriye'de örgütün sözde üst düzey yönetiminden birinin tecavüzüne uğramas1 sonucu hamile kalması ile gerçekleşmiştir. Kadın teröristin hamile olduğunun öğrenilmesi sonucu Öcalan tarafindan Dicle Nehri'ne atılıp öldürülmüştür. ${ }^{61}$ Benzer şekilde örgüte ait kanallarda TSK'nın bombardımanı sonucunda öldügü iddia edilen Rabia Kaya isimli kadın teröristin otopsi raporunda ise PKK'l1 teröristlerce tecavüz edildikten sonra infaz edildiği ortaya çıkmıştır. ${ }^{62}$

Temmuz 2019'da PKK'dan kaçarak güvenlik güçlerine teslim olan "Garan" kod adlı terörist de örgütün sözde üst yönetim kadrosunda bulunan terörist Cemil Bayık'ın kadınların özgürlüğünden bahsetmesine rağmen örgüt içerisinde kadınlara karşı hem psikolojik hem cinsel hem de fiziksel şiddet uyguladığından bahsetmiştir. Söz konusu cinsel istismarların örgüt içerisinde herkes tarafından bilindiğini ve durumun örtbas edilerek kadının susturulduğunu ya da infaz edildiğini itiraf etmiştir. Aynı zamanda sözde yönetim kadrosunda yer alan terörist Cemil Bayık'ın tecavüzü sonucu hamile kalan bir kadın teröristin Suriye'de kamptan uzaklaştırıldığını, kadının kaçmaya çalışması sonucunda ise infaz edildiğini dile getirmiştir. ${ }^{63}$

PKK içerisinde kadın teröristler yalnızca sözde üst düzey yöneticilerin değil, aynı zamanda diğer erkek teröristlerin de cinsel istismarına maruz kalmaktadır. Söz konusu istismarlara dayanamayarak kaçan kadınlar güvenlik güçlerine teslim olarak PKK içerisinde kadınların

\footnotetext{
61 "Dağda Önce Tecavüz, Sonra İnfaz", Sabah, 20 Şubat 2019, https://www.sabah.com.tr/ gundem/2019/02/20/dagda-once-tecavuz-sonra-infaz, (Erişim Tarihi: 10.09.2020).

62 "PKK/KCK Terör Örgütünün Çocukları ve Kadınları İstismarı", Türkiye Cumhuriyeti İ̧̧işleri Bakanlığl, Şubat 2017, s. 44, http://bern.emb.mfa.gov.tr/Content/ assets/consulate/images/localCache/12/4fe86f07-3dad-4fef-b77f-0018a008c177.pdf, (Erişim Tarihi: 10.09.2020).

63 “Terör Örgütü PKK'nın Kirli Yüzünü Anlattı", TV100, 13 Temmuz 2019, https://www.tv100.com/teror-orgutu-pkknin-kirli-yuzunu-anlatti-haber-463337, (Erişim Tarihi: 04.11.2020).
}

\section{7}

Güvenlik Stratejileri

Cilt: 17

Say1: 37 
148

Güvenlik Stratejileri

Cilt: 17

Sayı: 37

"özgürleştirilme” yalanıyla sömürüldüğünü gözler önüne sermektedir. 17 yaşındayken örgüte katılan "Nirvana" kod adlı teröristin teslim olmasının ardından yapmış olduğu itirafları buna örnek olarak gösterebiliriz.

"Örgütün tüm organları içinde geçen yıllarımda, kadınların uğradığ 1 taciz ve tecavüzleri gördüm ve kendim de yaşadım. Örgütün ve erkek üyelerinin kadına bakış açıları fikri tüm bağlarımı kopardı. Yaşadığım ve gördüğüm cinsel tacizlere artık dayamayınca, artık örgütte kalamayacağımı ve kendime çektirdiğim cezanın yettiğini düşünerek kaçtım." ${ }^{64}$

PKK içerisinde yaşanan tecavüzler sonucu hamile kalan kadınlara ya hayati riski olmasına rağmen zorla kürtaj yapıldığı ya infaz edildikleri ya da doğurdukları çocukların Avrupa'ya satıldığı bilinmektedir. ${ }^{65}$ Zira kürtaj meselesi Almanya'da Düsseldorf Eyalet Mahkemesi'nde bir dava konusu da olmuştur. PKK'nın Stuttgart sorumlusu "Ahmet" kod adlı terörist tarafindan tecavüze uğrayan kadın teröristin hamile kalması sonucu kürtaja zorlandığı ve kabul etmemesi halinde ölümle tehdit edildiği ortaya çıkmıştır. 2008 yılında gerçekleşen olayda kadın terörist; "Kürtajı kabul etmeyince silahl 2 PKK'lı tarafindan örgütün Avrupa sorumlusu ile görüştürülmek üzere zorla Brüksel'e götürüldüğünü, burada da kürtaja zorlandığını" dile getirmiştir. Kadın terörist kürtaj sonrasında da birçok kez intihar teşebbüsünde bulunduğunu ifade etmiştir. ${ }^{66}$

Örgütün en önemli gelir kaynaklarından olan uyuşturucunun, teröristlerin cesaretlenmesi ve silahlı eylemlere katılmasını teşvik etmek amacıyla kullanıldığı bilinmektedir. Ancak örgüt içerisinde kadınların cinsel istismara ses çıkarmaması ve mecburi bir rıza göstermesi için uyuşturucu bağımlısı yapıldığı da teslim olan teröristlerin ifadelerine

64 'Nirvana' Kod Adlı PKK'lı Teröristten İğrenç İtiraflar: Cinsel Tacizlerine Dayanamadım”, Takvim, 3 Aralık 2019.

65 “PKK'dan İğrençlikte Son Nokta! 'Tam Bir Sapıklık'...”, Milliyet, 18 Şubat 2019, https://www.milliyet.com.tr/gundem/pkkdan-igrenclikte-son-nokta-tam-bir-sapiklik2829446, (Erişim Tarihi: 18.02.2020).

66 "PKK'de Tecavüz ve Kürtaj”, Cumhuriyet, 2 Temmuz 2009, https://www.cumhuriyet. com.tr/haber/pkkde-tecavuz-ve-kurtaj-71132, (Erişim Tarihi: 12.09.2020). 
PKK’da Kadın Teröristlerin Rolü ve Örgüt İçi Cinsel İstismar

yansımıştır. TSK'nın Suriye'de gerçekleştirmiş olduğu Zeytin Dalı Harekâtı'nda yakalanan Leyla isimli terörist, örgüte katıldıktan iki hafta sonra kamplarda kendilerine cesaret hapları ve uyuşturucu verildiğini dile getirmiştir. Böylece örgüt, kamplardaki teröristleri silahlı eylemlere katılmaları için cesaretlendirip ölüme hazırlamış hem de cinsel istismarı kolaylaştırmayı sağlamıştır. Afrin'de örgüt sorumlusunun evinde kaldığ 2 gün boyunca uyuşturucu verilerek birçok kişi tarafından tecavüze uğradığını dile getiren kadın terörist, bunu neden yaptıklarını sorduğunda ise "verilen eğitimin karşılığı" yanıtını aldığını belirtmiştir. ${ }^{67}$

Özellikle PKK gibi seküler terör örgütleri içerisinde yer alan kadın teröristlerin, örgüt adına olumlu birçok katkısı bulunmaktadır. En önemlisi ulusal ve uluslararası medyada savaşan kadın imajının hem toplumsal hem psikolojik düzeyde oldukça etkili olmasıdır. Kadınlar terör örgütlerinde hem savaştırılmakta hem de propaganda aracı olarak kullanılmaktadır. Aynı zamanda kadınlar cinsel sömürüye maruz kalarak terör örgütleri için en önemli konumda olan erkek teröristlerin örgüte bağlılı̆̆ını da sağlamak amacıyla kullanılmaktadır. Terörist başı Öcalan tarafından yapılan kadın tanımlamasında yer alan “özgürleşecek kadınlar-tanrıçalar” ifadelerinin, örgüte terörist devşirmek amacıyla kullanılan manipülatif söylemler olduğunu söylemek yanlış olmayacaktır. Zira kadın teröristlerin örgüt içerisinde erkeklerle eşit konumda bulunmadığı ve hatta örgüte katılmadan önce daha özgür oldukları kadın teröristler tarafından da ifade edilmektedir. Yalnızca erkekler tarafından eşitsizliğe maruz kalmamakla birlikte kadınlar, örgüt içerisindeki kadınlar arasında da eşitsiz bir yapının bulunduğundan söz etmektedir. Her türlü eşitsiz bir muameleyle karşılaşan kadınlar arasındaki hiyerarşinin ise Öcalan'ın cinsel sömürüsüne maruz kalmakla belirlenmesi, örgüt içerisinde kadınların karşılaştıkları zulmü gözler önüne sermektedir.

67 "Kadın Terörist ‘İki Gün Tecavüze Uğradım”, Yeniçă̆, 20 Mayıs 2018, https://www.yenicaggazetesi.com.tr/kadin-terorist-2-gun-tecavuze-ugradim-192969h.htm, (Erişim Tarihi: 12.09.2020). 
150

Güvenlik Stratejileri

Cilt: 17

Sayı: 37

\section{Sonuç}

Çalışmada öncelikle terör örgütlerinde kadınların aktif rolü üzerinde durulmuş ve kadınlara terör örgütlerinde duyulan ihtiyacın sebebi anlatılmıştır. Genellikle kadınlara terör örgütlerinde verilen roller; kuryelik, bekçilik, taşımacılık, temizlik gibi ikincil roller olmuştur. Ancak bunların dışında, kadın teröristlerin cinsel sömürü ile erkek teröristlerin terör örgütlerine olan bağlılığını sağlama konusunda da bir köprü vazifesi görmesi istenmiştir. Aynı zamanda toplumda kadınların görece daha pozitif ve barışçı olduklarına yönelik algı dolayısıyla kadınlar kontrol noktalarından daha kolay geçmekte ve özellikle kendilerine hamile imaj1 vermeleri durumunda çoğu zaman üzerleri dahi aranmamaktadır. $\mathrm{Bu}$ nedenle kadın teröristler, terör örgütleri tarafından özellikle intihar saldırılarında daha sik tercih edilmektedir. Kadın teröristler aynı zamanda toplumda var olan kadınerkek ilişkilerindeki eşitsiz yapı dolayısıyla da intihar saldırılarıyla örgüt içerisindeki erkeklere kendilerini ispatlamak istemektedirler.

Dünyada birçok terör örgütü içerisinde yer alan kadın teröristler, PKK içerisinde de aktif rol almaktadır. PKK'nın terör eylemlerine başladığı ilk senelerde kadına daha çok "örgütü yozlaştıran" birer varlık olarak bakılırken, 1990'lardan sonra Sovyetler Birliği'nin yıkılmasının ve aile yapısına yönelik eleştiriler yönelten Marksist ideolojinin gücünü kaybetmesinin etkisiyle örgüt, kadına olan bakış açısını değiştirmiştir. Bu dönemde kadınlara yönelik "özgürleştirilecek tanrıçalar" söylemi geliştirilmiş ve sözde "Kürdistan'ın' kurtuluşunun ancak kadınların özgürleşmesiyle gerçekleşeceği" iddia edilmiştir. Kadınların söz konusu özgürleşmesinin ise sözde "feminist" bir yapıya sahip olduğu iddia edilen terör örgütüne katılarak gerçekleşebileceği ifade edilmiştir. Özellikle Doğu Anadolu ve Güneydoğu Anadolu Bölgelerinde yerel halktaki PKK algısını olumlamak amaciyla silahlı kadın teröristler meydanlarda boy göstermiş ve küçük yaşta evlendirilen, okutulmayan, aile içi şiddet gören kadınları etkileyerek örgüte eleman devşirme hedeflenmiştir. Tüm bu sebeplerden örgüte katılan kadın teröristler, Öcalan'ın toplumun kadın-erkek eşitliğine dayanması gerektiği söylemlerine itibar etmiştir. Ancak örgüte katılan kadın teröristler, erkek teröristlere göre daha çok ikinci plana atılmıştır. 
PKK'daki kadın teröristler her ne kadar örgütün sözde yönetiminde söz sahibi olsa da örgüt yönetiminin hem erkeklerin sayıca fazla olması hem de örgütün sözde yönetim kadrosunda son sözü erkek teröristlerin vermesi dolayısıyla kadın teröristlerin konumunu sembolik olarak değerlendirmek mümkündür.

Kadın teröristlere örgüt içerisinde çoğunlukla ikincil roller verilmesinin yanı sıra, kadınlar örgüt içerisinde sıkça cinsel istismara maruz kalmış ve gerek güvenlik güçlerinin raporlarında gerekse teslim olan/yakalanan teröristlerin itiraflarında söz konusu cinsel istismarlar dile getirilmiştir. Cinsel kimliği kullanılarak kadın teröristler hem terörist başı Öcalan'ın hem sözde yönetim kadrosunun hem de diğer erkek teröristlerin tecavüzlerine maruz kalmış/kalmaktadır. Öcalan ve sözde yönetim kadrosu tarafından adeta bir hak olarak görülen cinsel istismarlar, kadın teröristleri örgütten kaçma veya intihar etme arasında tercih yapmak zorunda bırakmıştır. Zira söz konusu istismarları şikâyet etmeleri durumunda örgüt tarafindan "devlete ajanlık yapmakla suçlanarak" infaz edilmektedirler. Aynı zamanda kadın teröristlerin hamile kalması durumunda ya zorla kürtaj yapıldığı ya doğan çocuğun Avrupa'ya para karşı1lı̆ında satıldığı ya da kadın teröristin infaz edildiği terörist itiraflarında dile getirilmektedir. $\mathrm{Bu}$ nedenle PKK içerisinde "özgürleştirilmesi gereken kadınlar", "tabularının yıkılması" için birer cinsel köle haline getirilmektedir.

PKK'da erkek teröristler karşısında ikincil öneme sahip kadın teröristlerin kendi içerisinde dahi bir eşitlik olmadığı anlaşılmaktadır. Zira kadın teröristler arasında da belirli bir hiyerarşi olduğu ve bu hiyerarşinin belirlenmesinde de güzelliğin en önemli ölçüt olduğu dile getirilmektedir. Kadın teröristler arasındaki hiyerarşi ise Öcalan'ın "özel eğitim" adı altında kadın teröristleri istismar etmesiyle belirlenmektedir. Tarihsel süreç içerisinde PKK'nın kadın tanımlaması sıklıkla değişmesine rağmen kadınların örgüt içerisindeki rolünün çok fazla değişmediği görülmektedir. Örgüt içerisinde yaşanan tüm bu şiddet, örgütün kadınlara yönelik eşitlikçi söylemleri ile faaliyetleri arasında büyük bir zıtlık olduğunu göstermektedir. Yani Öcalan'ın ve örgütün “özgürlük" ve "eşitlik" söylemlerine inanarak/inandırılarak PKK'ya katılan kadın teröristlerin dışarıdaki hayatından çok daha fazla köleleştiği

\section{1}

Güvenlik Stratejileri

Cilt: 17

Say1: 37 
152

Güvenlik Stratejileri

Cilt: 17

Sayı: 37

ve bu söylemlerin gerçeği yansıtmadığı açıkça görülmektedir.

Sonuç olarak çalışmada; kadınların terör örgütlerine kadın-erkek eşitliği, ataerkil düzene karşı mücadele gibi motivasyonlarla katılarak özgürleşmeyi umduğu ve örgütün de böyle bir eşitlik varmış gibi bir alg1 oluşturduğu, ancak PKK içerisinde özgürlüklerine kavuşmanın aksine daha çok köleleştikleri tespit edilmiştir. Özellikle PKK çevre terörü, örgüt içi infaz, çocuk savaşçı kullanımı gibi eylemleri nedeniyle algısını değiştirmek isteyerek propagandaya ihtiyaç duymakta ve dolayısıyla söz konusu propagandayı da örgütün "özgürleşen kadın" söylemleriyle gerçekleştirmek istemektedir. Aynı zamanda kadınların örgütte aktif rol aldığı ve "feminist bir devrim" gerçekleştireceği iddialarıyla uluslararası toplumdan destek bulma talebi içerisine de girmektedir. Zira örgüt, özellikle "feminizm" üzerinden bir kadın terörist algıs1 oluşturmaya çalışarak Türkiye'nin terörle mücadele operasyonlarının meşruiyetinin sorgulanmasını da istemektedir. Her ne kadar özellikle uluslararası medyada PKK'nın bu manipülatif söylemleri karşılık bulsa da gerçekliğin tamamen farklı olduğu, PKK içerisinde kadın teröristlerin özgür olmadığı, Öcalan tarafından oluşturulmak istenen "özgürleşen kadın" imajının gerçeği yansıtmadığı ve kadın teröristlerin maruz kaldığı cinsel istismarın göz ardı edildiği görülmektedir.

\section{Summary}

With the increase in the visibility and activity of terrorist organizations, changes also observed in the structure of terrorist organizations. Especially, important changes have occurred regarding terrorist organizations' perception of women. As women became more visible in society, the perception of women in terrorist organizations also changed and women started to be preferred by terrorist organizations. Women terrorists have been given various roles within both secular and religious terrorist organizations. When terror studies and studies on women are considered, there are many different motivations for terrorist organizations to prefer women. Besides fighting and suicide attacks, women take also place in secondary roles such as cook, security personnel, cleaner, and courier. In addition to these roles of female 
terrorists, it is known that they are used as "honey traps" and "baits" to attract male terrorists and pull them into the organization. Thus, the internal structure of the organization is protected through the sexual identity of women.

Within the scope of this study, the PKK was chosen as a case and the role of female terrorists in the PKK was explained. While PKK and organization leader Abdullah Öcalan's definition of women was initially based on the discourse of "women who corrupt men", it later turned into "women to be liberated". The most important reason for this change in the discourse of the PKK, a Marxist organization, is the collapse of the USSR. With the change in the PKK's discourse on women, women terrorists started to take an active role in the organization. As a result of women joining the PKK as a "way of escape" due to reasons such as domestic violence, deprivation of education, forced marriage at an early age, it is seen that women do not become emancipated, as Öcalan claimed in his statements. According to captured/surrendered terrorists' statements, besides using women for suicide attacks, they are also often given secondary roles and are literally used as slaves within the PKK. At the same time, the PKK uses women's sexual identity as a bait for keeping men in the organization, as other terrorist organizations do.

Although emotional and sexual relations between women and men are prohibited within the PKK, female terrorists are frequently exposed to sexual harassment and rape by Öcalan's so-called management staff and other male terrorists. The rape of women terrorists by Öcalan is attempted to be legitimized as "breaking taboos". It can be stated that the so-called management staff of the organization regard these sexual abuses as so to speak a right. Furthermore, in the confessions of the arrested/surrendered terrorists it is stated that if womens exposed that they were raped and sexually abused, they were punished with isolation or execution.

Another problem faced by female terrorists within the PKK is the inequality amongst women. Although the organization emphasizes gender equality in its propaganda activities, it is seen that there is inequality between women and men within the organization, and it is even understood that there is inequity amongst women. While female terrorists who have passed Öcalan's "special training" live in better conditions and

\section{3}

Güvenlik Stratejileri

Cilt: 17

Say1: 37 
154

Güvenlik Stratejileri

Cilt: 17

Sayı: 37

have access to all kinds of personal care products they need, other female terrorists are exploited in the mountains under difficult conditions. While physical beauty is the most important criterion in determining women, who have "undergone special training" by Öcalan, these women are exposed to rape and violence by him.

In this study, which deals with the role of women in terrorist organizations, the role of female terrorists in the PKK is analysed. Following the PKK's and Öcalan's definition of women and the explanation of why they prefer women in the organization, the motivations of women to participate in suicide attacks are explained. Finally, the inequalities that women terrorists encounter within the organization are discussed. Inequality between men and women and the rape and sexual abuse faced by women are explained by a mixed methodological method. Using both the news in the media and the confessions of the captured/surrendered terrorists, the contradiction between the PKK's women's discourse and the exploitation of women inside the PKK analysed in this study.

\section{Kaynakça}

Kitaplar

ALKAN, Necati. PKK'da Semboller, Aktörler, Kadınlar, Karınca Yayınları, Ankara, 2017. BULDAN, Nejdet. PKK'de Kadın Olmak, Doz Yayınları, İstanbul, 2004.

ÇAĞLAYAN, Handan. Analar, Yoldaşlar, Tanrıçalar: Kürt Hareketinde Kadınlar ve Kadın Kimliğinin Oluşumu, İletişim Yayınları, İstanbul, 2017.

HAMILTON, Carrie. Women and ETA: The Gender Politics of Radical Basque Nationalism, Manchester University Press, Manchester, 2007.

MATHEWS, Ann. Renegades: Irish Republican Women: 1900-1922, Mercier Press, 2010.

SCHWEITZER, Yoram. Female Suicide Bombers: Dying for Equality?, Tel Aviv University, Jaffee Center for Strategic Studies, 2006.

YILMAZ, Aytekin. Son Diktatör, Vadi Yayınları, İstanbul, 2020.

Makaleler

ALİ, May-Rukh. "ISIS and Propaganda: How ISIS Exploits Women", University of Oxford Reuters Institute for the Study of Journalism, 2015, 1-25. 
PKK'da Kadın Teröristlerin Rolü ve Örgüt İçi Cinsel İstismar

DEAN, Valentina. "Kurdish Female Fighters: The Western Depiction of YPJ Combatants in Rojava", Glocalism: Journal of Culture, Politics and Innovation, 2019, Say1 1, 1-29, https://glocalismjournal.org/wp-content/uploads/2019/05/Dean_gjcpi_2019_1.pdf, (Erişim Tarihi: 22.01.2020).

ERDEM, Nergiz. "Kadın Terörist Kimliğinin Psiko-Sosyal Kökenleri ve Sosyal Politikalar", Güvenlik Çalışmaları Dergisi, Aralık 2017, Cilt 19, Sayı 3, 8-26.

GALVIN, Deborah M. "The Female Terrorists: A Socio -Psychological Perspective", Behavioral Sciences \& The Law, 1983, Cilt 1, Say1 2, 19-32.

O'ROURKE, Lindsey A. "What's Special about Female Suicide Terrorism?", Security Studies, 2009, Cilt 18, Say1 4, 681-718.

SPECKHARD, Anne. "Female Terrorists in ISIS, al Qaeda and 21rst Century Terrorism", Trends Research, May1s 2015, 1-9, https://www.researchgate.net/profile/Anne_ Speckhard/publication/277204743_Female_Terrorists_in_ISIS_al_Qaeda_and_21rst_Centu ry_Terrorism/links/556472a908ae86c06b6a76c5/Female-Terrorists-in-ISIS-al-Qaeda-and21rst-Century-Terrorism.pdf, (Erişim Tarihi: 11.09.2020).

TÜRK, H. Bahadır. "Hegemonic Masculinity and Terrorism: The Case of The PKK and Abdullah Öcalan", Critical Studies on Terrorism, 2020, Cilt 13, Say1 2, 258-279.

ZEDALIS, Debra D. "Female Suicide Bombers", The Strategic Studies Institute, Haziran 2004, 1-18.

\section{Raporlar ve Tezler}

"PKK/KCK Terör Örgütünün Çocukları ve Kadınları İstismarı", Türkiye Cumhuriyeti İçişleri Bakanlığl, Şubat 2017, http://bern.emb.mfa.gov.tr/Content/assets/consulate/images/ localCache/12/4fe86f07-3dad-4fef-b77f-0018a008c177.pdf, (Erişim Tarihi: 10.09.2020).

5th Gobal Report: Sexual Exploitation New Challenges, New Answers, Fondation Scelles, 2019, http://fondationscelles.org/pdf/RM5/5th_Global_Report_Fondation_SCELLES_2019_ download.pdf, (Erişim Tarihi: 28.10.2020).

ÇEBİ, Şükrü Okyar. "Terörizm Olgusu İçerisinde Kadın Militanların Analizi". Yayınlanmamış Yüksek Lisans Tezi. 2010.

ÖZCAN, Nihat Ali. ve Gürkaynak, Erdem. "Kim Bu Dağdakiler”, TEPAV, 10 Şubat 2012, https://www.tepav.org.tr/upload/files/1335350447-4.Kim_Bu_Dagdakiler.pdf, (Erişim Tarihi: 16.10.2020).

\section{İnternet Kaynakları}

"Dağda Önce Tecavüz, Sonra İnfaz", Sabah, 20 Şubat 2019, https://www.sabah.com.tr/ gundem/2019/02/20/dagda-once-tecavuz-sonra-infaz, (Erişim Tarihi: 10.09.2020).

"İște PKK'daki Tecavüz Dehşetinin Belgesi! Duran Kalkan'ın Video Kaydını Verdi....", Takvim, 22 Kasim 2019, https://www.takvim.com.tr/guncel/2019/11/22/iste-pkkdakitecavuz-dehsetinin-belgesi-duran-kalkanin-video-kaydini-verdi, (Erişim Tarihi: 11.09.2020).

“İște PKK'nın İğrenç Yüzü! İki Kadını Yanına İstedi, Önce Tecavüz Etti Sonra...”, A Haber, 30 Ocak 2019, https://www.ahaber.com.tr/gundem/2019/01/30/iste-pkkninigrenc-yuzu-iki-kadini-yanina-istedi-once-tecavuz-etti-sonra, (Erişim Tarihi: 11.10.2020).

"Kadın Terörist 'İki Gün Tecavüze Uğradım", Yeniçağ, 20 Mayıs 2018, https://www.yenicaggazetesi.com.tr/kadin-terorist-2-gun-tecavuze-ugradim-192969h.htm, (Erişim Tarihi: 12.09.2020). 
156

Güvenlik

Stratejileri

Cilt: 17

Sayı: 37
"Kandil Dağı'ndan Yaşanmış Tecavüz Hikayeleri”, Hürriyet, 5 Şubat 2006, https://www.hurriyet.com.tr/kelebek/kandil-dagi-ndan-yasanmis-tecavuz-hikayeleri-3886942, (Erişim Tarihi: 12.09.2020).

"Nirvana' Kod Adlı PKK'lı Teröristten İğrenç İtiraflar: Cinsel Tacizlerine Dayanamadım", Takvim, 3 Aralık 2019, https://www.takvim.com.tr/guncel/2019/12/ 03/nirvana-kod-adli-pkkli-teroristten-igrenc-itiraflar-cinsel-tacizlerine-dayanamadim, (Erişim Tarihi: 12.09.2020).

“Öcalan'1n Suriye Günleri”, Habertürk, 6 Eylül 2011, https://www.haberturk.com/ yasam/haber/666525-ocalanin-suriye-gunleri, (Erişim Tarihi: 21.09.2020).

"Pakistan Terror Groups Use Women to 'Honey Trap' Youths: Officials", Economic Times, 3 Aralık 2018, https://economictimes.indiatimes.com/news/defence/pakistan-terror-groupsuse-women-to-honey-trap-youths-officials/articleshow/66906490.cms?utm_source= contentofinterest\&utm_medium=text\&utm_campaign=cppst, (Erişim Tarihi: 30.10 .2020$)$. "PKK Elebaşı Karayıllan'ın Tecavüz Ettiği Kadın Terörist El Bombasıyla Kendini Patlattı", Haberler.com, 10 Ağustos 2018, https://www.haberler.com/pkk-elebasikarayilan-in-tecavuz-ettigi-kadin-11132995-haberi/, (Erişim Tarihi: 12.09.2020).

"PKK Örgütü Dosyası: Bin 150 Kadın İtirafçıdan PKK'nın Tecavüz ve İnfazları", Özel Büro İstihbarat Grubu, https://www.ozelburoistihbarat.com/teror/pkk-orgutu-dosyasi-bin150-kadin-itirafcidan-pkknin-tecavuz-ve-infazlari-9129, (Erişim Tarihi: 12.09.2020).

"PKK'dan İğrençlikte Son Nokta! 'Tam Bir Sapıklık'...", Milliyet, 18 Şubat 2019, https://www.milliyet.com.tr/gundem/pkkdan-igrenclikte-son-nokta-tam-bir-sapiklik2829446, (Erişim Tarihi: 18.09.2020).

"PKK'de Tecavüz ve Kürtaj”, Cumhuriyet, 2 Temmuz 2009, https://www.cumhuriyet. com.tr/haber/pkkde-tecavuz-ve-kurtaj-71132, (Erişim Tarihi: 12.09.2020).

"PKK'nın 'Tecavüz Üssü' Kandil! Kadın Terörist PKK'nın Kirli Yüzünü Anlattı", Sabah, 9 Kasım 2019, https://www.sabah.com.tr/gundem/2019/11/09/pkknin-tecavuzussu-kandil-kadin-terorist-pkknin-kirli-yuzunu-anlatti, (Erişim Tarihi: 12.09.2020).

"Sebahat Tuncel İntihar Bombacisını Övdü", NTV, 1 Temmuz 2011, https://www.ntv.com.tr/turkiye/sebahat-tuncel-intihar-bombacisini-ovdu,qeC-UAv0d U2bEsQKWKOZcQ, (Erişim Tarihi: 21.08.2020).

“Terör Örgütü PKK'nın Kirli Yüzünü Anlattı”, TV100, 13 Temmuz 2019, https://www.tv100.com/teror-orgutu-pkknin-kirli-yuzunu-anlatti-haber-463337, (Erişim Tarihi: 04.11.2020).

SPRİNZAK, Ehud. "Rational Fanatics", Foreign Policy, 20 Kasim 2009, https://foreignpolicy.com/2009/11/20/rational-fanatics/, (Erişim Tarihi: 21.08.2020). 